\title{
IDEA DE LA JUSTICIA A TRAVÉS DE LA ICONOGRAFÍA DE LAS BIBLIAS MEDIEVALES DE BOLONIA (SIGLOS XIII-XIV) LOCALIZADAS EN ESPAÑA
}

\author{
POR \\ Ma . ConCepción Martínez Murillo \\ Editorial CSIC
}

\section{RESUMEN}

Análisis de la representación iconográfica de la virtud de la Justicia en el Libro de la Sabiduría de las Biblias de Bolonia (siglos XIII y xIV) localizadas en España. La interpretación iconográfica se completa con el contexto histórico y la influencia de la disciplina del Derecho en Europa y, en especial, en Bolonia.

Palabras ClaVe: Biblia, manuscrito, Libro de la Sabiduría, Edad Media, Bolonia, España, siglos XIII y XIV, iconografía, justicia, ley, derecho, herejía, ortodoxia, rey, espada, balanza, poder.

\section{THE IDEA JUSTICE THROUGT THE ICONOGRAPHY OF BIBLES MEDIEVAL OF BOLOGNA (XIII AND XIV CENTURIES) LOCATED IN SPAIN}

\begin{abstract}
Analysis of the iconographic representation of the virtue of justice in the Book of Wisdom contained in the Bibles of Bologna (XIII and XIV centuries) located in Spain. The iconographic interpretation is supplemented by the historical context and the influence of the discipline of law in Europe and especially in Bologna.

KeY WORDS: Bible, manuscript, Book of Wisdom, Middle Ages, Bologna, justice, Spain, iconography, XIII and XIV centuries, iconography, justice, law, heresy, orthodoxy, king, sword, libra , authority.
\end{abstract}


Ma CONCEPCIÓN MARTÍNEZ MURILLO

\section{INTRODUCCIÓN}

La justicia es y ha sido siempre un tema de total actualidad; en la cultura de Occidente, una de sus principales fuentes de inspiración normativa y legislativa ha sido la Sagrada Escritura y sus representaciones, tanto en el discurso escrito como en el arte figurativo. ${ }^{1} \mathrm{El}$ «concepto de justicia», representado en las Biblias procedentes de la influyente Escuela de Bolonia, se aborda en este estudio desde dos perspectivas que son propias de la disciplina del arte: la «iconográfica», que es ante todo estética o comunicativa, que corresponde a la descripción y al reconocimiento de las imágenes, y la «iconológica» que sirve para comunicar ideas y descifrar el significado de las imágenes; método usado para descifrar las alegorías. Las dos perspectivas se complementan, y por consiguiente, para abordar el estudio iconográfico (término que uso en líneas generales) utilizo la «descripción preiconográfica», perteneciente al campo de los sentidos, por medio de la cual reconozco la obra de arte. El siguiente paso es el descriptivo -«análisis iconográfico»- por el que identifico las imágenes, historias y alegorías contenidas en la obra de arte de forma meramente detallada y cualitativa. Finalmente, en cuanto a las características que se atribuyen a la imagen, que no son de tipo interpretativo, uso el «análisis iconológico», auxiliado por disciplinas como la historia, la filosofía, la literatura y el derecho, especialidades por las que desarrollo la interpretación del contexto histórico, cultural y social para contribuir a penetrar e interpretar a través de la imagen, las creencias y las formas de pensar, en términos generales, condensadas en los manuscritos procedentes de Bolonia. ${ }^{2}$

Las Biblias que he escogido son obras lujosas, ricamente iluminadas, auténticas Vulgatas que tuvieron, en su momento, una gran difusión y expansión en Europa, de las que se piensa hubo un verdadero mercado. Contaron con una notable clientela que trascendió al siglo xv, entre la que destacaron personajes de la iglesia, de la nobleza y de la corona.

\footnotetext{
${ }^{1}$ Véase, como ejemplo, el análisis en: Rodríguez López, Blanca. 2013. «Por qué ser justos. ¿Son las normas de justicia sociales o morales?». Revista Internacional de Sociología, vol 72, $\mathrm{n}^{\circ} 2$ : 261-280 y en <http://revintsociologia.revistas.csic.es/index.php/revintsociologia/article/view/511/533> (Consulta: fecha de consulta: 5/2013)

${ }^{2}$ Sobre el método iconográfico e iconológico véase: Panofsky, Erwin. 1976. Estudios sobre iconología. Prólogo de Enrique Lafuente Ferrari. Versión española de Bernardo Fernández, 2a edición. Madrid: Editorial Alianza Universidad; Grabar, André. 1985. Las vías de la creación en la iconografía cristiana. Versión española de Francisco Díez del Corral. Editorial Alianza Universidad. Colección Alianza Forma; Sebastián López, Santiago. 1996. Mensaje simbólico del arte medieval. Arquitectura, liturgia e iconografía. $1^{\text {a }}$ edición. Madrid: Ediciones Encuentro; Castiñeiras González, Manuel Antonio. 1998. Introducción al método iconográfico. $1^{\text {a }}$ edición. Barcelona: Editorial Ariel, S.A. También, Burke, Peter. 2001. Visto y no visto. El uso de la imagen como documento histórico. Barcelona: Crítica.
} 
Marco histórico y Características generales de las Biblias PRocedentes de BOLONIA

Los cuatro manuscritos que presento incluyen entre sus imágenes representaciones distintas que alegorizan la virtud. Se trata de la Biblia de Palacio Real de Madrid (ms. II-330); Biblia del Real Monasterio de El Escorial (ms. a. I. 5); Biblia de Burgo de Osma (Ms/3) y Biblia de la Biblioteca Nacional (Vit. 21-4). Los cuatro pertenecen desde el punto de vista estilístico al grupo de códices de la escuela boloñesa emiliana de la segunda mitad del siglo XIII y primer tercio del XIV. ${ }^{3}$ Por el contrario, no analizamos aquí la Biblia de la catedral de Gerona ni la Biblia de la Catedral de Plasencia, también boloñesas, por razones cronológicas y de ámbito geográfico, aunque serán ineludibles algunas referencias a lo largo de estas páginas.

Nos encontramos ante una producción de manuscritos lujosos, no sólo por la calidad artística de sus miniaturas sino también por los materiales utilizados en su decoración: se usa el oro, pan de oro, azul de ultramar, materiales todos ellos caros. El soporte empleado es el pergamino avitelado a gran folio. ${ }^{4}$

Características formales comunes a los cuatro códices son la existencia de Prólogos y Argumentos que preceden los Libros sagrados tomados, la gran mayoría, de las Epístolas de San Jerónimo (especialmente la Epístola 53 a Paulino de Nola al comienzo del Génesis y la reproducción de la Epístola a Desiderio en el Prefacio al Pentateuco). Otros datos materiales a destacar: a) reproducción del prólogo de Hugo de San Caro (Santo Caro, un dominico francés que vivió entre los años finales del siglo XII y principios del XIII) en el Libro de los Salmos (folio 280 v: "Quoniam super omnes scripturas...) en el ms. $a$. I. $5,{ }^{5}$ b) relación de estas Biblias con el correctorio de París y la orden dominicana por la existencia de textos que interpretan los «nombres hebreos», concretamente en el ms.a.I. 5 (fol. 475) atribuido al teólogo benedictino Remigii

\footnotetext{
${ }^{3}$ Véanse referencias en Domínguez Bordona, Jesús. 1933. Manuscritos con pinturas. Notas para un inventario de los conservados en colecciones públicas y particulares de España. 2 Tomos: Tom. I (ÁvilaMadrid). Tom. II (El Escorial-Zaragoza). [Ms. II-330 (Fondo antiguo: 2-G-5 y Olim: IV-D-3): Tom. I: 467, n catalogo: 1124. Ms. a. I. 5: Tom. II: 5-6, n ${ }^{\circ}$ de catálogo: $1248 . ~ M s / 3$ : Tom. II: 158, 161, n ${ }^{\circ}$ catálogo: 1749. Vit. 21-4 (fondo antiguo Ol. 25): Tom. I: 383, 384, n catálogo: 938]. Centro de Estudios Históricos. Fichero de Arte Antiguo. Madrid: Imprenta Blass S. A.

${ }^{4}$ Domínguez Bordona, Jesús. 1925. «Miniaturas Boloñesas del siglo XIV». Archivo Español de Arte y Arqueología 4: 177-188.

${ }^{5}$ Antolín, Guillermo. 1916. Catálogo de los Códices Latinos de la Real Biblioteca de El Escorial, Vol. IV: 332. Madrid: Imprenta Helénica. El dominico Hugo de San Caro perteneció al Correctorio Parisiense que surgió para restaurar el texto original de la Vulgata y sustituyó al Correctorio Senonense de la orden dominica por una orden dada en el Capítulo General de 1256. Hugo de San Caro $(† 1236)$ junto con otros teólogos dominicos del Convento de Santiago de París elaboraron el Correctorio Parisiense también llamado Correctorio dominico.
} 
Autissiodorensis ${ }^{6}$ (Remy d Auxerre) maestro de la escuela de Saint Germain d'Auxerre, de Reims y de París. De la misma manera, la interpretación de los nombres hebreos se contempla en el manuscrito (Vit. 21-4, antiguamente Olim A, 25) del teólogo benedictino.?

Considero que hubo un verdadero mercado de códices por la abundante producción de este tipo de manuscritos en los siglos XIII y XIV ejecutados en el «estudio boloñés», según se detecta en los catálogos y a través de los estudios de los especialistas. Producto de ello fue la gran difusión y expansión que llegaron a alcanzar en Europa. Idea mía, expuesta en otros trabajos, es que uno de los motivos de que surgiera semejante profusión fue la necesidad de instrumentos de propaganda para una serie de ideas expresadas por vía iconográfica, tales como la defensa de la ortodoxia, de la fe y de las Escrituras. Un hecho muy probable podría haber sido que estas Biblias, realizadas en el «estudio boloñés», hubieran sido encargadas por o para la orden dominicana con el objeto de combatir las herejías cuyas causas expondré más adelante. ${ }^{8}$ Es conocida la producción de manuscritos boloñeses ricamente iluminados compuestos en los scriptoria o studia monásticos y algunos laicos que empiezan a surgir en el siglo XIII con el nacimiento de las Universidades. Según algunos autores, muchos de estos manuscritos fueron exportados a Europa Occidental y, entre ellos, los boloñeses. Se plantea entre los especialistas como hipótesis, que los de carácter más lujoso iban dirigidos a una clientela de destacada posición social y económica. Pere Bohigas afirma que ya en el siglo xIII surge el comercio de la librería ante la gran demanda de códices, la variedad de lectores y de clientes, algunos de ellos con gran interés por acrecentar sus bibliotecas como fue Richard de Bury, Obispo de Durham (1287-1345) Canciller de Enrique III de Inglaterra. La petición a gran escala de libros a los scriptoria ocasiona la proliferación de copias, como es el caso de las Biblias de París y los manuscritos jurídicos de Bolonia. ${ }^{9}$ Entre esa clientela se conocen figuras destacadas de la iglesia (primera mitad del siglo XIII) y en fechas más avanzadas personalidades relevantes de la Corona y de la Iglesia española (siglos XIV y Xv) que residieron o visitaron Bolonia, y adquirieron o tuvieron en su poder las Biblias producidas en Bolonia. De acuerdo con el catálogo de Jesús Domínguez Bordona, la Biblia Boloñesa de Gerona atribuida al maestro Bernardino de Modena perteneció en 1378 a Carlos

${ }^{6}$ Antolín, Guillermo. 1916: 331.

${ }^{7}$ De la Torre, Martín y Longás, Pedro. 1935. Catálogo de Códices Latinos. Tomo I: 62. Madrid: Patronato de la Biblioteca Nacional. Véase además la referencia a Remigius de Saint Germain d'Auxerre, O. S. B. (ca. 841-908), en: <http://rbme.patrimonionacional.es/Busqueda-en-Catalogo.axp?id=4 > .

${ }^{8}$ Formentín, Justo y Martínez Murillo, Mª . Concepción. 1994: «Influencia de la Leyenda Dorada en la literatura y en el arte medieval, a través de dos Biblias boloñesas localizadas en España». Hispania Sacra XLVI, no. 93: 84-86.

${ }^{9}$ Bohigas, Pere. 1980. «En qué medida el estudio histórico de las Bibliotecas contribuye al conocimiento de los contactos culturales en la Edad Media»: Boletín de la Anabad XXX: 209-224. 
V (de Francia) que la compró al convento de Saint-Lucien de Beauvais; de ahí se cedió en préstamo al obispo de esa ciudad Jean de Dormans. A su muerte, el códice pasó a la biblioteca del Louvre y en 1383-84 la poseía el Duque de Berry. Años después el obispo Dalmacio de Mur -embajador de Alfonso V- la adquirió en París, donándola en 1456 a la catedral de Gerona. A este personaje perteneció también la Biblia del Real Monasterio de el Escorial (ms. a .I. 5), según he podido identificar en el margen derecho del folio 1 (Epístola 53 de San Jerónimo a Paulino de Nola) en el que aparece el escudo de Dalmacio (Dalmau) de Mur (Mur i Cervelló, obispo de Gerona y arzobispo de Tarragona y Zaragoza, mecenas de las artes, quién la regaló a Felipe IV, rey de España. La Biblia de la Catedral de Plasencia, aunque boloñesa y conservada en el archivo capitular de la catedral de Plasencia, es al menos de un siglo posterior a las biblias que analizo en este trabajo, pues data del siglo XV y por tanto no es objeto de nuestro estudio. Según Jesús Domínguez Bordona perteneció a don Gonzalo de Zúñiga y tal vez sea la que figura en un inventario de 1452 de don Álvaro de Zúñiga, Duque de Béjar. La familia estuvo muy relacionada con la orden dominica; su corte literaria y mecenazgo fue de gran importancia en España según se recoge en el trabajo de Fernando Villaseñor Sebastián.

La Biblia del Palacio Real de Madrid (ms. II-330) fue propiedad del Conde de Gondomar, Diego Sarmiento de Acuña (1567-1626), ya que esta Biblia consta en su inventario de 1623 según el «Catálogo de la Biblioteca y la Base de datos bibliográfica de Patrimonio Nacional». Conocido diplomático español, Álvaro de Zúñiga fue caballero noble de la orden de Calatrava, embajador de España en Inglaterra (1613 y 1622), erudito y bibliófilo que llegó a reunir una de las bibliotecas privadas más importantes del siglo XVII, posteriormente cedida por el Marqués de Malpica a Carlos III en 1785. Otros datos materiales que aparecen en la Biblia de Palacio y que puedan arrojar más información, son los siguientes: una rúbrica en el margen inferior del folio 1 (Epístola 53 de San Jerónimo a Paulino) que según Domínguez Bordona es del siglo XVIII, en la que se lee el nombre de Gulielmi Cecilii. Al final -o sea, en el Índice Bíblico Doctrinal, en el último folio mutilado y a plumilla- en letra del siglo XVI, aparece otra rúbrica en la que se lee: Cicilla. dm. Sobre la Biblia de la Biblioteca Nacional (ms. Vit. 21-4., antiguamente Olim. A, 25) las únicas referencias que conozco es que fue «escrita en 1272 por Juan, hijo de Jacobo, para un convento dominico, probablemente del Norte de Italia. ${ }^{10}$

\footnotetext{
${ }^{10}$ Referencias tomadas de: Domínguez Bordona, J. 1933. Manuscritos con pinturas. Tom. I: 104, 140-143, 383, 467: Tom. II: 5-6. La misma procedencia sobre la Biblia de Plasencia en Ayuso Marazuela, Teófilo. 1953. La Vetus Latina Hispana. Tomo I. Madrid, 379. Otros datos en Yarza, Joaquín. 2006. «Manuscritos iluminados boloñeses en España. Siglos XIII-XIV» en: España y Bolonia. Siete siglos de relaciones artísticas y culturales: 31, 38-39. Joaquín Colomer y Amadeo Serra Desfilis (directores). Madrid: Edita la Fundación Carolina y Centro de Estudios de Europa Hispánica. IBIS. Base de datos del
} 
Desde el punto de vista iconográfico las Biblias boloñesas son Biblias en imágenes, en las que el dibujo y la pintura se ordenan en el folio ocupando, de modo sistemático, el espacio interior de la letra capital. En las Biblias más avanzadas ( $m s$. II-330 y ms. a. I.5) el orlado invade los márgenes, especialmente el margen inferior y en ocasiones el superior. Se ilustra tanto el Antiguo Testamento como el Nuevo, a medida que las explicaciones literales-bíblicas o simbólico morales lo sugieren. Este modo de ilustrar es típico de los siglos XIII Y XIV.

La iconografía de las Biblias boloñesas se subordina de forma manifiesta a los tres divinos sentidos propuestos por San Jerónimo, necesarios a la hora de interpretar las Escrituras: a) Sentido literal o histórico por el que se ordenan las «imágenes directas» del Antiguo y Nuevo Testamento que expresan fielmente lo escrito y las «imágenes indirectas» que tienen como oficio ilustrar textos difíciles de ser interpretados. Son las llamadas «imágenes o escenas atemporales»; b) sentido tropológico, lenguaje figurado o alegórico: se organizan las «imágenes alegóricas» relacionadas con la moral y la doctrina; c) sentido espiritual o típico al que corresponden las imágenes y objetos que revelan aspectos de la vida espiritual; a este sentido pertenecen las «imágenes tipos», también llamadas «prefiguras mesiánicas», y las imágenes y objetos relacionadas con la liturgia. Para la interpretación de este tipo de iconografía se recurre a los Santos Padres de la Iglesia (especialmente a San Agustín a través de su obra La Ciudad de Dios), a las Epístolas de San Jerónimo y a la Leyenda Dorada (Legenda Sanctorum), obra hagiográfica de gran valor patrístico y teológico considerada atractivo manual de meditación y lectura espiritual, código educativo del cristiano y fuente inagotable de inspiración iconográfica para el arte durante los siglos XIII y XIV. La obra pretende mostrar a los fieles los caminos de perfección cristiana y animarles a seguir el ejemplo de los santos. ${ }^{11}$ Compuesta en 1264, es obra del dominico Santiago de la Vorágine (Jacopo da Varagine). ${ }^{12}$ Este tipo

patrimonio bibliográfico de Patrimonio Nacional <http://realbiblioteca.patrimonionacional.es/cgi-bin/ koha/opac-detail.pl?biblionumber=387> (Consulta 06/09/2014) y <http://rbme.patrimonionacional. es/Busqueda-en-Catalogo.aspx?id=4 > (8/09/2014). Villaseñor Sebastián, Fernando. 2013. «La corte literaria de Juan de Zúñiga y Pimentel (Plasencia, 1459-Guadalupe, 1504) en: Anales de Historia del Arte 23: (nº especial II) 581-594.

${ }^{11}$ Véase Formentín Ibáñez, Justo y Martínez Murillo, Ma . Concepción. 1994: 65-139. También, Martínez Murillo, $M^{\mathrm{a}}$. Concepción y Formentín Ibáñez, Justo. 1995. «Iconografía relacionada con la vida de los santos en algunas miniaturas de la «Biblia Boloñesa del Real Monasterio de El Escorial» (ms. a. I. 5): Influencia de la Leyenda Dorada» en: Hispania Sacra XLVII, nº .96: 695-745.

${ }^{12}$ Santiago de la Vorágine fue un dominico relevante en su orden. Las fechas que conviene tener presentes, en el marco histórico en el que se minian las Biblias Boloñesas, son las siguientes: prior del convento de Asti en 1260; desde 1267, provincial de la Provincia de la Lombardía; en 1283, una vez muerto Juan de Vercelli, fue nombrado vicario general de la orden; en 1286, arzobispo de Génova.

Hispania Sacra, LXVII

135, enero-junio 2015, 7-47, ISSN: 0018-215X, doi: 10.3989/hs.2015.001 
de imágenes refleja la preocupación por la defensa de la fe católica y la recta interpretación de las Escrituras.

El texto de estas Biblias no sufre alteración alguna por la iconografía. Se distribuye en el folio a dos columnas, con un número de líneas que oscila entre cincuenta y siete y sesenta, escritas en bella letra o littera bononiense como la denomina Jesús Domínguez Bordona: «Es tan perfecta de forma cuanto copiosa y arbitraria en abreviaturas». ${ }^{13}$ La escritura, también llamada escolástica, monacal o alemana, se manifiesta en sus variantes mayúscula y minúscula. ${ }^{14}$

Respecto a los textos y versiones, siguen el orden establecido por la Biblia de París, elaborada en la Universidad de París ${ }^{15}$ en 1235, exenta ya de los errores y contaminaciones que se habían ido acumulando a lo largo del tiempo; su uso estuvo en vigencia hasta el siglo XVI.

En relación al contexto histórico en el que se ilustran las Biblias boloñesas en Italia, existió un fenómeno social por el que comenzaron a expandirse doctrinas contrarias a los dogmas de fe católicos, lo que trajo consigo el establecimiento de la Inquisición en Italia, especialmente en Bolonia. Las herejías de cátaros, valdenses y albigenses, ampliamente difundidas en el Languedoc francés, en el norte de Italia y también en España, especialmente en la Corona de Aragón, ${ }^{16}$

${ }^{13}$ Domínguez Bordona, Jesús. 1925: 177 y ss.

${ }^{14}$ Sosa, G. 1966. El arte del libro en la Edad Media: 29-33. Buenos Aires. figuras 16-17. Millares Carlo, A. 1929. Paleografía Española: Vol. I: 217 Barcelona-Buenos Aires. Millares Carlo, A. 1933. Introducción a la historia del libro y de las bibliotecas: 48. Madrid.

${ }^{15}$ La Biblia de París surge por la corrupción existente del texto jeronimiano; en su estructura intervino, como es sabido, la orden de santo Domingo. A grandes rasgos, las características comunes de éstas Biblias con las boloñesas, son las siguientes: a) contienen el texto de la recensión de Alcuino, pero aumentando las interpolaciones y otras recensiones; b) aparece por primera vez el esquema de división en capítulos de las Sagradas Escrituras, que comenzó a utilizar Esteban de Langton en 1203-4; c) todas empiezan con la «Epístola 53 de San Jerónimo a Paulino de Nola» (traducción del latín al castellano de esta epístola en: Cartas de San Jerónimo. 1962. Tomo I: 431-443. Edición bilingüe latín-castellano. Introducción, versión y notas por Daniel Ruiz Bueno. Madrid: Biblioteca de Autores Cristianos (en adelante BAC); d) los prefacios, prólogos y argumentos de San Jerónimo se anteponen, sistemáticamente, a casi la totalidad de los Libros.

${ }^{16}$ En España se difundieron, especialmente, en la Corona de Aragón a mediados del siglo XIII; aunque la herejía valdense fuera objeto de legislación de Alfonso II y Pedro II en 1194 y 1198 . En 1241 el Obispo Berenguer de Palou de Barcelona establece el tribunal inquisitorial en su diócesis. En 1242 el dominico y abogado (experto en leyes) Raimundo de Peñafort (Penyafort) establece las formas de actuar y organiza la legislación en el Concilio de Tarragona de 1242. En 1231 Gregorio IX envía la Bula Declinante iam mundi vespere al arzobispo de Tarragona Aspàreg (Asparragon de Barca) y a sus sufragáneos. En la Bula avisa como a través de ciertas imágenes evolucionan las herejías en España y exhorta a la Inquisición para controlarlas. Pone al Tribunal en manos de obispos y dominicos. Véanse Martínez Millán, José. 1980. «En torno al nacimiento de la inquisición medieval a través de la censura de libros en los reinos de Castilla y Aragón 1232-1480»: Hispania, n 144: 5-35. Llorca, B.; García Villoslada, Ricardo; De Leturia, P.; Montalban, F. J. 1953. Historia de la Iglesia Católica. Tomo II: Edad Media: 837-838. Madrid: BAC. Pons Gurí, Joseph María. 1974. «Constituciones conciliares 
produjeron errores en materia de fe que dieron lugar a falsas interpretaciones de las Escrituras. Todo esto unido a enseñanzas erróneas de los textos sagrados por clérigos mal instruidos, produjo el advenimiento de doctrinas heterodoxas. El efecto inmediato fue la emisión de un decreto conciliar en el IV Concilio Lateranense, en 1215, por el que se ordenaba establecer la Inquisición Episcopal para extirpar las mencionadas herejías. ${ }^{17}$ De forma simultánea y como réplica a la relajación del clero, surgió en Italia un nuevo modo de vida cristiano y una espiritualidad específicamente secular, de gran peso en la sociedad, cuyo reflejo fueron la aparición de las cofradías de laicos ${ }^{18}$ y el nacimiento de las órdenes religiosas de dominicos y franciscanos, cuyo protagonismo fue decisivo en esa religiosidad. ${ }^{19}$

La facilidad con la que pudieron penetrar las herejías maniqueas en Italia a través de las costas mediterráneas se explica porque siempre mantuvo relaciones comerciales con el Oriente bizantino. Sin embargo, Bolonia, plaza amurallada, a la vez que ciudad universitaria por excelencia, fue uno de los centros de reacción antiherética más importantes.

Los conventos dominicos italianos de Bolonia fueron los principales focos difusores de frailes predicadores para la defensa del dogma en la península italiana. Por tal motivo Pierre Dominique calificó de «cuartel general de la Inquisición» a la ciudad de Bolonia. ${ }^{20}$

La primera fundación de los frailes Predicadores en Bolonia data de 1218. Dos años después, tras haber enviado cuatro frailes para establecer un Instituto

tarraconenses 1229-1330». Analecta Sacra Tarraconensia, vol. XLVII: 34; Smith, Damian. 2013. «Cruzada, herejía e inquisición en tierras de la Corona de Aragón ss. XII-XIII»: Hispania Sacra Vol. LXV (Extra I) enero-junio: 29-48; Martínez Murillo, Ma . Concepción. 1999. «Las Biblias boloñesas medievales y la defensa de la ortodoxia a través de sus imágenes»: V Simposio Bíblico Español. La Biblia en el arte y la Literatura. II Arte: 324-327. Universidad de Navarra. Valencia-Pamplona.

${ }^{17}$ Llorca, B., García Villoslada, Ricardo et alii, Ibídem: 592-595.

${ }^{18}$ Entre las cofradías de laicos se distinguen, fundamentalmente, dos tipos: las cofradías tradicionales de antigua o nueva fundación. Eran piadosas asociaciones de asistencia material y espiritual, conectadas a un santo patrono, un santuario etc.; la más antigua entre ellas es la «Congregación boloñesa de Santo Domingo», de 1224. Otro tipo de cofradías nacidas de la lucha contra los patarrinos y cátaros de la Lombardía, estaban organizadas para el combatir la herejía; algunas fundadas por el propio Pedro de Verona. Entre ellas son conocidas la «Sociedad de la fe» y la «Sociedad de la Virgen». Asociaciones análogas se fundaron en Florencia, Bolonia, y Bérgamo. Respecto a «Las Milicias de Jesucristo» —en lucha contra los albigenses- su difusión fue menor, y a ellas estuvieron asociadas, especialmente, los nobles de Parma: Véase Dictionnaire de Spiritualité (Ascétique et Mystique, Doctrine et Histoire) 1932-1988. Marcel Viller S. J. (director). F. Cavallera y J. De Guibert, S. J. (colaboradores) Vol. VII. 1968: 22082214. Beauchesnes-París.

${ }^{19}$ En 1216, Honorio III aprobaba las reglas de los franciscanos, dominicos y carmelitas. El 16 de julio de ese mismo año, se aprobó el Instituto formado por Domingo de Guzmán contra los herejes: Llorente, Juan Antonio. 1822. Historia crítica de la Inquisición en España. Cap. XLVII: 22-23. Madrid.

${ }^{20}$ Dominique, Pierre. 1969. L'Inquisition: 97-99. París.

Hispania Sacra, LXVII

135, enero-junio 2015, 7-47, ISSN: 0018-215X, doi: 10.3989/hs.2015.001 
próximo a la Universidad, Santo Domingo llega en persona a la ciudad. Después de una breve estancia en Roma fija su residencia en el convento de San Nicolás de Bolonia, casa en la que permaneció hasta su muerte en 1221. En ese mismo año se habían celebrado los primeros capítulos generales de la Orden, en los que se definieron sus principales objetivos: ejercer un apostolado al servicio de los laicos, desde los centros intelectuales de Bolonia y París, y centrase en la predicación, la confesión y la dirección espiritual siguiendo las prescripciones del IV Concilio de Letrán de $1215 .{ }^{21}$ A partir de aquí, se acaban de escribir las primeras Summae; de ellas, una de las más importantes la Summa contra Gentiles de Santo Tomás de Aquino, escrita a petición de San Raimundo de Peñafort, se concluye en 1264. La finalidad de esta obra, importantísima en la lucha contra la herejía, era la de ayudar en el diálogo y labor misionera entre los judíos y musulmanes. La intención es manifestar, en la medida de lo posible, la verdad que profesa la «fe católica» eliminando los errores contrarios (capítulo II del Libro I). Otra de las obras de Santo Tomás es la Summa Theológica, citada al inicio de este trabajo. Santo Tomás de Aquino muere en 1274 y fue canonizado el dieciocho de julio de 1323 por el papa Juan XXII. ${ }^{22}$ En esos momentos la Inquisición ya existe en Italia bajo la dirección de los dominicos. ${ }^{23}$

La Orden de los hermanos de San Francisco, coetánea a la de los dominicos, reaccionó contra el desorden social espiritual proponiendo un retorno a la imitación literal de la vida de Cristo, el Cristo pobre. En 1220 San Francisco aparece obrando milagros y en 1223 predica en Bolonia. ${ }^{24}$ La expansión de la Orden, una vez aprobada por Inocencio III, fue rápida y creciente. A juicio de Emilio Gebhart, «la conversión de los herejes parece haber preocupado más a la Orden de Predicadores que a los hermanos de San Francisco. Los franciscanos se dedicaron más a la conversión de los infieles de Tartaria, China y Egipto que a emplearse en la conversión de herejes. La Orden Franciscana no entendía de las profundidades de la teología estimando, medianamente, las ciencias profanas, las letras y los libros». ${ }^{25}$

En 1245 el papa Inocencio IV convocó el XIII Concilio Ecuménico de Lyón. En ese Concilio se manifestaron, entre los males que afectaban a la Iglesia, el

${ }^{21}$ Fecha en la que tiene lugar la aprobación pontifical de la regla y su sometimiento a la de San Agustín: Dictionnaire de Spiritualité (Ascétique et Mystique, Doctrine et Histoire). 1932-1988: 2209-2210.

$22<\mathrm{http} / /$ www.dominicos.org/grandes-figuras/santos/santo-tomas-de-aquino/biografia-ysemblanza -espiritual $>($ Consulta:11/11/2013)

${ }^{23}$ Llorente, Juan Antonio, 1822: Cap. X: 24.

${ }^{24}$ Muratori,L.A. 1912-1932. Storici Italiani. Tom.XVIII-Part.I/L. Vol. II: 86-87. Corpus Chronicorum Bononiensium. Cittá di Castello.

${ }^{25}$ Gebhart, Emilio. 1943. La Italia mística. Historia del Renacimiento religioso en la Edad Media: 96 Buenos Aires. 
de los pecados de los prelados y de sus súbditos, y el cisma de los griegos. Al mismo tiempo se extendió un anatema contra Federico II -entonces excomulgado- y como consecuencia se entabló una lucha entre güelfos y gibelinos en Italia. Los frailes mendicantes predicaron contra el rey. Al año siguiente, en 1246, el papa otorgó un Breve concediendo al general de los dominicos y a sus sucesores el cargo de ser los delegados, por la Santa Sede, para proceder contra los herejes. ${ }^{26}$ Un acontecimiento importante tuvo lugar en Italia, en 1252, la muerte del dominico e inquisidor Pedro de Verona, asesinado en Milán a manos de un hereje maniqueo.$^{27}$ De este suceso nos ha quedado constancia iconográfica en el margen inferior del Génesis del ms. II-330. Para entonces, la actividad inquisitorial estaba en toda su pujanza provocando que, especialmente entre 1243 y 1254, se hiciera mucho hincapié en el envío de dominicos españoles a Italia para ejercer el oficio de Inquisidores. ${ }^{28}$ Poco después, mediante otro Breve del papa Inocencio, se concedió a los dominicos el privilegio de ser los únicos inquisidores en España. ${ }^{29}$

En el plano literario conviene también recordar que en 1264 el dominico Santiago de la Vorágine compuso la ya citada Leyenda Dorada, obra hagiográfica de gran difusión desde la misma fecha en la que se redactó, puesto que los franciscanos y los dominicos la emplearon intensamente como texto de predicación para el pueblo. La obra tuvo también una extraordinaria influencia en el arte religioso, en general, y en la iconografía de las Biblias boloñesas ${ }^{30}$ como indico más arriba.

$\mathrm{Al}$ margen de estas órdenes, otras muchas comunidades religiosas se establecieron en Bolonia a lo largo del siglo XIII, para ayudar a mejorar el clima espiritual. Entre ellas, carmelitas, basileos armenienses, servitas y los «gaudenti». Esta última comunidad, formada por conventuales y personas casadas, había sido instituida para proteger a las viudas y huérfanos ocasionados por las

${ }^{26}$ Llorente, Juan Antonio. 1822: Cap. X. 27-28.

${ }^{27}$ Llorca, B., García Villoslada, Ricardo. Ibídem: 835. Véase también De Frachet, Gerardo. 1966. «San Pedro de Verona y su martirio»: Vida de los frailes predicadores» en: Santo Domingo de Guzmán. Su vida. Su obra: 625. Madrid: BAC. Koudelka, Vladimir J.1968. Bibliotheca Sanctorum. Tom. X: 748. Roma: Instituto Giovanni XXIII della Pontificia Universitá Lateranense.

${ }^{28}$ Braudrillard, Alfred. 1937. Dictionnaire d'Histoire et de Geographie Eclesiastiques. T. IX: 648659. Véase también Dictionnaire de Spiritualité (...). Ibídem: 2209-2210.

${ }^{29}$ Fernández Conde, J. 1982. «Aplicaciones de las reformas del Lateranense IV»: Historia de la Iglesia en España, Vol. II-2 : 47-58.

${ }^{30}$ En 1281 Santiago de la Vorágine visita España enviado por el papa Martín IV al frente de una Delegación Pontificia. El motivo de la visita de Santiago era conocer los objetivos del rey, Pedro III de Aragón, que en estos momentos preparaba una flota para combatir a los moros de África. Su trabajo principal consistiría en ejercer cierta labor diplomática mediando entre el rey y el Papa. El suceso es interesante porque demuestra, una vez más, la movilidad de los dominicos. Ver Formentín Ibáñez y Martínez Murillo, Ma de la Concepción. 1994: 70.

Hispania Sacra, LXVII

135, enero-junio 2015, 7-47, ISSN: 0018-215X, doi: 10.3989/hs.2015.001 
guerras civiles. En último extremo -como sostiene Ladero Quesada- para recuperar la ortodoxia, lo primero que se empleó fue la predicación y la polémica catequética, y posteriormente la Inquisición, establecida por Gregorio IX en 1229 como medida represiva. Respecto a la eficacia de los distintos métodos, se puede sostener que la herejía cedió más a causa de la predicación de las órdenes mendicantes y de otros movimientos eclesiásticos, que a la represión Inquisitorial. ${ }^{31}$

La preocupación social por el problema de la herejía se descubre a través de algunas imágenes miniadas en las Biblias boloñesas. A través de sus imágenes se defiende la ortodoxia de los errores propagados en materia de fe. Entre las representaciones que hacen alusión al problema de la herejía en las Biblias boloñesas valdría la pena destacar las siguientes: martirio del dominico Pedro de Verona asesinado por un hereje de la secta maniquea representado en el Génesis del $m s$. II-330; variadas representaciones del hereje a través de un ser antropomorfo «hombre con cuello de avestruz»; ciertas representaciones satíricas del clero (clericis concubinariis). Por el contrario se representan otras manifestaciones acordes con la ortodoxia católica: la «humanidad de Cristo» y la «maternidad de María». Representación de escenas o imágenes que hacen alusión al problema de la controversia religiosa son: la exaltación y veneración de los mártires por la fe (martirio de Isaías); se resalta la importancia de los sacramentos (orden sacerdotal, bautismos, jerarquía eclesiástica, etc.); representación continua de las órdenes religiosas, especialmente la dominica; escenas alegóricas de virtudes en contraposición al vicio; exaltación del Libro como símbolo y fuente de revelación, de la ley y de la fe; fieles en actitud de fe; continuas representaciones de la presencia divina a través de «caras lunares. ${ }^{32}$

Llegados a este punto podríamos resumir lo que antecede en la siguiente formulación: las Biblias boloñesas, auténticas Vulgatas fueron hechas con una finalidad claramente apologética, para defender la ortodoxia y la fe católica. Se observa una fuerte conexión entre las Biblias miniadas en Bolonia y la Orden de Predicadores, por el fuerte espíritu dominico que se detecta en ellas, especialmente a través del análisis iconográfico y de datos históricos que las rodean. Es muy posible que se ilustraran en el «estudio boloñés» por encargo de la orden dominicana. Los dominicos necesitaban el texto auténtico de las Sagradas Escrituras, ediciones de auténticas Vulgatas, para profundizar en sus contenidos y poder rebatir así las nuevas herejías. Los contenidos de la Vulgata, en las Biblias boloñesas, proporcionarían, además de la belleza espiritual de la

${ }^{31}$ Ladero Quesada, Miguel Ángel. 1987. Historia Universal. Edad Media. Vol. II: 542. Barcelona: Vicens-Vives.

${ }^{32}$ Véase Martínez Murillo, Mª . Concepción. 1999: 327-338. 
palabra auténtica inspirada, sin contaminaciones erróneas, la belleza plástica de las miniaturas.

El convento dominico de Bolonia había alcanzado, a finales del siglo XIII, un enorme prestigio por la proyección doctrinal y apostólica de sus religiosos; es muy probable que estos difundiesen las Biblias boloñesas por otras casas de su Orden ubicadas en distintas ciudades de Europa. ${ }^{33}$

LA Filosofía JuRídica del DeREChO: LA INFLUENCIA ARISTOTÉLICA EN ESCRITORES ECLESIÁSTICOS DE LOS SIGLOS XIII AL XIV. LA ESCUELA DE GLOSADORES Y EL DERECHO EN BOLONIA

En la segunda mitad del siglo XIII se empieza a traducir al latín las obras de Aristóteles; es el periodo denominado por Y. Congar «la tercera entrada de Aristóteles». ${ }^{34}$ Aunque con anterioridad ya se había manifestado en este campo la influencia aristotélica, ${ }^{35}$ ésta será especialmente intensa en materias relacionadas con la moral y la política entre los años 1240 y 1270 . Como resultado, los teólogos asumieron una nueva filosofía o conocimiento racional de la naturaleza de las cosas y de las estructuras psicológicas del hombre.

En este contexto, desde el punto de vista de la ética, Aristóteles entiende la justicia (virtud moral y virtud política y social) orientada al bien ajeno, y es por eso la más perfecta de las virtudes morales. Es una virtud que radica, como potencia espiritual, en la voluntad. Todas las demás virtudes quedan bajo la determinación de la Justicia, entre cuyas características se distinguen: la alteridad, la igualdad o reciprocidad y la exigibilidad. La Justicia, continúa Aristóteles, practica la equidad, que se regula por medio de la Ley, que es universal y se aplica

${ }^{33}$ La lectio divina (lectura diaria de la Biblia) costumbre propia del monacato, fue adoptada y practicada por las órdenes religiosas. Los fieles piadosos, como los terciarios, también hacían uso de la lectura de las Escrituras que, a su vez, eran comentadas por un clérigo responsable.

${ }^{34}$ Congar, Y. M. J. 1981: 313-314.

${ }^{35}$ Recordemos que la influencia de Aristóteles se deja sentir en el pensamiento social, de forma gradual, a lo largo de varios siglos. Se conocen tres vías de penetración: la primera transmisión, a los latinos, se realiza a través de Boecio (†524 ó 525) en su obra Opuscula Sacra: trabajo en el que se transmite la lógica de Aristóteles. Esta obra sería leída por el teólogo y filósofo del renacimiento carolingio Juan Escoto Erígena y por el teólogo escolástico francés del siglo XII Gilberto de la Porrée. En la Edad Media se elabora una metafísica del «ser» o del esfuerzo especulativo de la definición de la noción de la persona. Otra obra de Boecio, De Consolatione Philosophiae resultado de la mezcla de elementos filosóficos-aristotélicos y de metafísica platónica sería leída en el siglo XV por el teólogo, humanista, jurista y político Tomás Moro. La segunda entrada de los escritos aristotélicos tiene lugar entre 1120 y 1160 y la tercera y última vía de penetración tiene lugar a finales del siglo XII y sobre todo en el XIII (1220), principalmente en París, y en especial en las universidades en las que se utilizan escritos cosmológicos. El desarrollo de las quaestio escolásticas se formularía mediante el instrumento lógico aristotélico.

Hispania Sacra, LXVII

135, enero-junio 2015, 7-47, ISSN: 0018-215X, doi: 10.3989/hs.2015.001 
a todos. La Justicia es una virtud total. El mejor hombre es «el justo», cuya naturaleza es la de buscar el beneficio del otro, dando a otros lo que es suyo (o justo) por naturaleza y por ley. La Justicia es, ante todo, un hallazgo racional y no un acto de voluntad ciega. Lo propio de la Justicia es conducir al hombre a la plenitud del espíritu. Sin la Justicia el hombre no alcanza la felicidad. ${ }^{36}$

En suma, la influencia de la filosofía de Aristóteles en el siglo XIII crea tendencia especialmente en escritores eclesiásticos de la talla de San Alberto Magno $(† 1280)$ y Santo Tomás de Aquino $(† 1274)$ quien traducirá en su Sententia libri Ethicorum, compuesta entre 1269 y 1272, algunas de las obras del filósofo griego, entre ellas la Ética Nicomáquea. Esta obra, de extraordinaria importancia en su momento, proporciona sólidos fundamentos ideológicos del concepto de Justicia utilizado en la ciencia jurídica medieval y sus representaciones iconográficas.

Desde el punto de vista jurídico, en el siglo XIII existe ya cierta autonomía de la sociedad con respecto al papado. Con anterioridad Ivo de Chartres $(\uparrow 1116)$, reputado especialista en Derecho canónico, cuyo protagonismo se había manifestado de forma especial en la «Querella de las Investiduras», innovó con sus teorías la distinción entre el poder temporal y el espiritual. Ivo de Chartres sostuvo que las investiduras no eran un sacramento, por lo que podían ser otorgadas por un laico.

A partir de esta problemática el Derecho civil y el canónico tuvieron especial relevancia en la Escuela de Bolonia, también conocida como «escuela de los jurisconsultos boloñeses» o «escuela de Glosadores», en la que se conocen cinco generaciones entre la primera mitad del siglo XI y el siglo XIII. Ésta fue una escuela interdisciplinar, en la que participaron reputados especialistas expertos en leyes: maestros, teólogos, glosadores y canonistas. La escuela fue fundada por el eminente jurista Irnerio, en el siglo XI, para estudiar el Derecho romano justinianeo; y en ella se usó la «glosa» o «exégesis textual», como método de estudio.

Del método de la «glosa» y de los trabajos de los glosadores surgieron las Concordandia discordantium canonum (Decreto Graciano, 1140-1142), obra de Graciano. La obra del monje jurista, profesor de teología en Bolonia, tuvo vigencia nada menos que hasta 1917. Sus Concordancias trataban de conciliar la totalidad de las normas canónicas existentes, en las que introdujo citas autorizadas de los Papas de siglos anteriores (muchas de ellas opuestas entre sí) y al mismo tiempo, incorporaba casos civiles y legales. En la obra de Graciano la teología se mezclaría con el Derecho canónico, práctica que a finales del siglo

\footnotetext{
${ }^{36}$ Contreras, Sebastián. 2012. «La justicia en Aristóteles. Una revisión a las ideas fundamentales de Ethicae Nicomachea»: Ágora. Estudios Clásicos en Debate 14: 63-80.
} 
XIII y principios del XIV sería común en la vida eclesiástica y en el terreno teológico, hasta el punto de que desde Alejandro III casi todos los papas fueron juristas y la gran mayoría de los hombres de la Iglesia hacían la carrera de Derecho. La colección más y mejor sistematizada del Derecho canónico postgracianeo se realiza entre 1230 y 1234 por el dominico español Raimundo de Peñafort, escolar y después maestro de teología en el Studium de Bolonia.

Gracias a Graciano, compilador de la ciencia legal de los cánones y decretos que dio lugar a la creación del primer boceto del Derecho eclesiástico, y a Irnerio, fundador del Derecho civil, Bolonia se convirtió en el lugar de estudio por excelencia del Derecho. Ésta disciplina pronto pasaría a ser «ciencia jurídica» independiente de la Retórica en la Universidad de Bolonia (antigua Academia y Alma Mater Studiorum en 1088), ${ }^{37}$ como consecuencia de la necesidad de independizar el poder temporal del eclesiástico (conflictos conocidos entre güelfos y gibelinos). Por ello renació el Derecho antiguo en la Universidad y la disciplina atrajo muy pronto a maestros y discípulos de toda Europa. ${ }^{38}$

Bolonia fue por tanto, el centro del estudio por la excelencia y alta especialización para quienes quisieran aprender leyes; mientras que en París se ejercía el monopolio de la enseñanza de la teología. La facultad de Derecho se había creado en Bolonia a través de escuelas privadas de leyes en 1222, aunque su fundación es anterior, de 1158, por Federico II Barbarroja. ${ }^{39}$ El método de enseñanza fue la escolástica, que provenía del siglo XII, mediante la lectio y la disputa. La Universidad de Bolonia -como otras de la época- se dividió en cuatro facultades: derecho, teología, artes y medicina.

A partir de la mitad del siglo XIII se registra un impulso de los estudios y prácticas jurídicas en la especialidad de la ciencia notarial boloñesa y de su escuela comunal no universitaria. El creciente interés del gobierno comunal por

${ }^{37}$ Dolcini, Carlo. 2007. «Lo Studium fino al XIII secolo» en: Storia di Bologna . Tom. 2: Bologna nel Medioevo: 477-498. Direttore Renato Zangheri a cura di Ovidio Capitani. Bononia: Edita University Press; Fundazione cassa di Risparmio in Bologna, Instituto per la Storia di Bologna.

${ }^{38}$ El estudio del Derecho en Bolonia deriva de las instituciones municipales romanas que continuaron funcionando durante la Edad Media. Originariamente el código legal del Imperio Romano tenía por oficio determinar la fuerza legal de los estatutos y decretos: Hernández, Gabriel, 2009. «Origen de las Universidades en Italia». Educación y Desarrollo Social. Vol. 3, 1: 182-190.

Sobre las fuentes del Derecho medieval en el caso español, véase: De Silva y Verástegui, Soledad. 1991. «Contribución al estado de la cuestión de los estudios iconográficos en los manuscritos jurídicos ilustrados de la Edad Media». Cuadernos de Arte e Iconografía: <http://www.fuesp.com/revistas/ pag/cai0715.html> (Consultado: 26/7/2013). En el estudio da referencias para la investigación de las miniaturas que ilustran los manuscritos jurídicos iluminados de la Edad Media. Cita, entre otras obras, las de A. Melnikas, sobre el Corpus de manuscritos iluminados del Decreto Graciano.

${ }^{39}$ Sánchez Mariana, Manuel. 1996. El Libro en la Baja Edad Media. Reino de Castilla: Historia ilustrada del Libro Español. Los manuscritos. Cap. 9: 175. Madrid: Edita la Fundación Germán Sánchez Ruipérez y Ediciones Pirámide, $2^{\circ}$ edición.

Hispania Sacra, LXVII

135, enero-junio 2015, 7-47, ISSN: 0018-215X, doi: 10.3989/hs.2015.001 
los asuntos notariales hace que se escriba en 1255 una obra de tanta importancia como la de Rolandini Passagerii, Summa artis notariae, sobre la legislación acerca de compraventas, donaciones, testamentos, etc., que causaría una fuerte impresión en el Studium y en la ciudad..$^{40}$ Así pues, el nacimiento de una nueva clase social de juristas y funcionarios fomentó la producción de abundantes textos legales. A partir de estos momentos el estudio del Derecho y su ejercicio estaría en todo su esplendor.

REPRESENTACIONES DE LA VIRTUd DE La JUSTICIA COMO INTERPRETACIÓN DEl DERECHO Y DE LAS LEYES EN LAS BiBLIAS BOLOÑESAS

A lo largo de los sucesivos siglos de la Edad Media la Biblia no se dejó de leer, pues era el ejemplo de vida; tampoco dejó de ser comentada, ya fuera en la predicación (sentido antiguo del Tractus) ya fuera para refutar las herejías o para nutrir la fe. La idea se encuentra en la segunda carta de San Pablo a Timoteo (2 Tim 3, 16-17) en la que la referencia a las Escrituras Santas, como enseñanza e instrucción divinamente inspiradas, así lo expresa: «Pues toda la Escritura es divinamente inspirada y útil para enseñar, para argüir, para corregir, para educar en la justicia, a fin de que el hombre de Dios sea perfecto y consumado en toda obra buena». ${ }^{41}$

La Biblia constituyó una de las enseñanzas básicas, la lectio divina (lectura divina, «lectura orante» del texto sagrado), metodología de reflexión y oración de un texto sagrado cuyos orígenes se remontan a los primeros años del cristianismo. La comprensión de la palabra de Dios, revelada en las Sagradas Escrituras, es tratada en el siglo XII por dos enfoques teológicos: el monástico y el escolástico. Ambos penetran en la ciencia teológica y en su tratamiento de diferentes maneras. La teología monástica persigue la edificación, dejando en segundo plano el discurso literario, mientras que la escolástica busca la interpretación por medio del «método exegético», procedimiento que se fue imponiendo de forma progresiva a finales del siglo XII y se implantaría definitivamente en los siglos XIII y XIV. Andrés de San Víctor (†1175) y Hugo de San Caro (†1263) fueron figuras destacadas en la revisión del texto de la Vulgata mediante el método exegético y la realización de las Concordancias verbales. ${ }^{42}$

\footnotetext{
${ }^{40}$ Dolcini, Carlo. 2007: 495-496.

${ }^{41}$ Para las citas bíblicas entrecomilladas y referencias (siglas de los textos bíblicos), en esta nota y en las posteriores, he utilizado la Sagrada Biblia. 1958. Versión directa de lenguas originales realizada por Nácar Fuster, Eloíno; Colunga, Alberto; Cigognani, Gaetano, 8ª edición. Madrid: Biblioteca de Autores Cristianos.

${ }^{42}$ Congar, Y. M. J. 1981. La fe y la teología: 311-313. Barcelona: Herder.
} 
En los siglos XIII y XIV el estudio de la teología llegó a ser una especialidad universitaria, por lo que en buena lógica adquirió un carácter más científico, ordenado y estructurado. Las Universidades medievales de Bolonia especialmente, seguida de las de París, Oxford, Cambridge, Padua, Nápoles, Toulouse, Montpellier, Coimbra, etc. impartían, entre otras materias, la enseñanza bíblica, que se explicaba durante cuatro años, aunque sólo ocupaba puesto relevante en la facultad de Teología. La Sagrada Escritura era comentada y leída mediante el método de razonamiento filosófico de la dialéctica, en un tiempo en el que el arte de dialogar, argumentar y discutir empezaba a despertar un gran interés. En este sentido la escolástica, movimiento teológico y filosófico que intentó utilizar la filosofía grecolatina clásica para comprender la revelación religiosa del cristianismo, utilizaba la dialéctica.

El apogeo de la escolástica coincide, en el siglo XIII, con la fundación de las órdenes mendicantes de dominicos y franciscanos, de las que procederían la mayoría de los teólogos y filósofos de la época. Del método escolástico surgieron las obras más leídas y comentadas en el siglo XIII y XIV: todo un universo de Summas $^{43}$ que influyeron en el pensamiento cristiano y, por consiguiente, en el arte destinado a difundirlo. Sin duda alguna el máximo representante de la teología, que influyó considerablemente en los siglos XIII y XIV, fue el dominico Santo Tomás de Aquino (1225-1274) especialmente con la Summa Theologiae, en la que se acepta el empirismo aristotélico y la teoría hilemórfica de la realidad física de las cosas y de los seres físicos. Santo Tomás llega a fusionar las dos tendencias filosóficas -la platónica y la aristotélica- en lo que sería el «tomismo»; escuela filosófica que surgió como legado de su obra y pensamiento. La delimitación entre filosofía y creencia religiosa en la filosofía de Tomás de Aquino inicia el proceso de independencia entre las cuestiones propias de la fe y de la razón, ${ }^{44}$ dicotomía que puede en ocasiones detectarse en las imágenes que estudiamos.

Sin duda, los acontecimientos mencionados, la repercusión del pensamiento de excelentes teólogos del momento, el desarrollo de la literatura y los estudios universitarios, especialmente la disciplina jurídica del derecho y la teología, influyeron decisivamente en la elaboración de la iconografía de los manuscritos bíblicos boloñeses.

${ }^{43}$ Entre las más destacadas: Summa de Creatoris de Alberto Magno (1240-1243), Summa Universae Theologiae de Alejandro de Hales (1245), Summa de Anima de Juan de la Rochelle (1245), Summa Theologiae de Santo Tomás de Aquino (1266-1274), Summa Theológiae inconclusa de San Alberto Magno (1270-)

${ }^{44}$ Con anterioridad, los Padres de la Iglesia y los precursores de la escolástica: Escoto Erígena, San Anselmo y Abelardo son conocedores de la facultad de la «razón» del hombre, como fuente principal del conocimiento y de la «gnosis».

Hispania Sacra, LXVII

135, enero-junio 2015, 7-47, ISSN: 0018-215X, doi: 10.3989/hs.2015.001 
Evidenciaremos, por tanto, a través de la iconografía de las Biblias boloñesas la trascendencia que tuvo el sistema legislativo y judicial (civil y religioso) en las representaciones iconográficas de la Justicia en Italia. ${ }^{45}$

En general, las imágenes de la Justicia, ya sean de origen civil o eclesiástico, se han representado de diferentes maneras a través de la historia. ${ }^{46}$ La forma de ilustrar el sistema legislativo a través de la iconografía de manuscritos italianos, que contienen imágenes relacionadas con la Justicia, nos orienta sobre las normas feudales jurídicas usadas en esos momentos de la Edad Media. Obras de carácter jurídico influyen en esa iconografía, las más destacadas: el Corpus Juris Cívilis de Justiniano, fundamento de la norma civil, junto con las «Constituciones», «Decretales Pontificias» y el «Decreto de Graciano» fundamentos que lo son de la norma eclesiástica. Estas obras se empiezan a miniar a principios del siglo XIII. Según Mario Salmi, «estos libros comienzan a ser glosados por medio de figuras aportando Bolonia una contribución original hasta finales del siglo XIII (...)». Y cita como ejemplos el Infortiatum de la Biblioteca Nacional de Turín, el Digestum del Colegio de España en Bolonia $\mathrm{n}^{\mathrm{o}} 282$ y el Decretum Gratiani de la Vaticana (ms. vat. lat. 1375) del siglo XIV obra de Jacopino da Regio. ${ }^{47}$ En este último manuscrito se representa una figura aureolada, entronizada; probablemente sea la representación de un personaje sagrado, en actitud de hacer entrega de las leyes canónicas y civiles a ministros de la iglesia y dignatarios que administran la Justicia. ${ }^{48}$ A mediados del siglo XIV se sigue trabajando en la decoración de manuscritos jurídicos italianos, ejemplo de ello, entre otros muchos, las famosas Decretales de la Vaticana (vat. lat. 1389), las Decretales de Bonifacio VIII, las Constituciones

${ }^{45}$ De la misma manera ocurre en el arte religioso coetáneo de otros países, en el que aparecen representaciones de la Justicia y de sus símbolos que manifiestan la importancia de la práctica jurídica civil asociada a lo religioso. Es el caso de la Catedral de León en España, en el que se representa la Justicia (portada occidental) concretamente en el llamado Locus Appellacionis (lugar donde se realizaban las apelaciones de la justicia) y se observa que las imágenes vinculadas a la Justicia también se vinculan al Libro Fuero Juzgo o Lex Visigothorum, utilizado en León entre los siglos XIII y XV. Un amplio y profundo estudio véase en: Franco Mata, Ángela. 1998. Escultura gótica en León y provincia 1230-1530: 202-212. León: Instituto Leonés de Cultura y Diputación de León. Véase también: Cavero Domínguez, Gregorio; Fernández González, Etelvina y Galván Freile, Fernando. 2007. «Imágenes reales, imágenes de justicia en la catedral de León»: $e$-Spania [puesto en línea el 26 de junio de 2007 , 25 noviembre 2009]: <http://e-spania.revues.org/document204> (Consulta: 5/6/2013) y http://e-spania. revues.org/204 (8/ 9/ 2014). DOI del artículo: 10.4000/e-Spania.204.

${ }^{46}$ Rodríguez López, María Isabel. 2003. «La imagen de la Justicia en las artes plásticas. Desde la antigüedad hasta las postrimerías del medioevo». Saberes. Revista de estudios jurídicos, económicos y sociales. Vol. I: 1-26 y <http://www.uax.es/publicaciones/archivos/SABSOC03_006.pdf.>

${ }^{47}$ Salmi, Mario. 1962. La miniatura Italiana: 15-19, fig. 17:18. Obra traducida por Juan G. Basté. Barcelona: Lábor. Sobre las Decretales iluminadas de Gregorio IX producidas entre 1270 y 1350 véase: Pavón Ramírez, Marta. 2007. Manuscritos de derecho canónico iluminados: las Decretales de Gregorio IX de la Biblioteca Apostólica Vaticana. Tesis doctoral. Barcelona.

${ }^{48}$ Salmi, Mario, Ídem. 
de Clemente V (A. 25), libros de coro, etc. Recordemos que al mismo tiempo se están ilustrando manuscritos bíblicos lujosos, como las Biblias boloñesas de gran formato, con imágenes alusivas a la Justicia.

Las Biblias boloñesas medievales localizadas en España, objeto de este estudio, representan conceptos relacionados con la Justicia que se contienen en el Libro de la Sabiduría. Por consiguiente, las miniaturas alusivas a la Justicia en las Biblias boloñesas nacieron para decorar ese Libro pero, además, sirvieron para ilustrar su contenido y reflejar el concepto de Justicia deseado. El Libro de la Sabiduría es, en las Biblias boloñesas, el escenario por excelencia de la representación de la Justicia.

El Libro de la Sabiduría es el libro sobre el arte de gobernar, que tiene como idea central la «justicia en el gobierno». No deja de ser un texto de Sabiduría, de tema sapiencial, pero que parte del convencimiento de que no existe sabiduría fuera de la Justicia. El Libro, según la tradición judeocristiana, se atribuye a Salomón. Su estructura, dividida en tres partes, alude a la sabiduría moral (beneficios que reporta y desventuras que trae la estulticia) en los capítulos 1-5; a la sabiduría intelectual (origen naturaleza y propiedades) en los capítulos 6-9; y demuestra los buenos efectos de la sabiduría en Israel, frente a los estragos de la estulticia de la idolatría entre los pueblos paganos (capítulos 10-19). Es de sabios ejercer bien la Justicia.

Es un libro de teología política; es decir, de reflexión sobre la política desde la fe. El autor del Libro finge ser el rey Salomón que escribe su obra para exhortar a los paganos a «Amad la justicia los que gobernáis la tierra (...)»(Sab 1,1), a «Aprended los que domináis los confines de la tierra (...) los que imperáis sobre la muchedumbre y los que os engreís sobre la multitud de las naciones (...)» (Sab 6,1) a buscar y practicar esa sabiduría-justicia, porque con ella se conseguirán todos los bienes imaginables, incluso la inmortalidad (Sab 1,15; 8,17). La inmortalidad es, según este autor, el primero y el único argumento que lo afirma en todo el Antiguo Testamento, el verdadero destino del hombre: Dios no hizo la muerte, ni goza destruyendo a los vivientes... Dios creó al hombre para la inmortalidad (Sab 1,13; 2,23).

La iconografía del Juicio de Salomón es uno de los temas más representados y escogidos, en la Edad Media. En las representaciones sobre la alegoría de la Justicia Salomón es el supremo juez, es el símbolo de monarca justo y sabio. ${ }^{49}$ El autor del Libro de la Sabiduría es Salomón, y la figura del rey que representa a Salomón es la de un rey teocrático con carácter sagrado. Salomón es el vicario

\footnotetext{
${ }^{49}$ Rodríguez López, María Isabel. 2006. «La imagen de la Justicia en la Edad Moderna: génesis y análisis iconográfico». Anales de Historia del Arte 16: 12.

Hispania Sacra, LXVII

135, enero-junio 2015, 7-47, ISSN: 0018-215X, doi: 10.3989/hs.2015.001
} 
de Dios, monarca justo, prototipo de la imagen del rey medieval. ${ }^{50}$ Salomón es el arquetipo del buen gobernante y prototipo de rey que contiene todas las virtudes necesarias para restablecer el orden originario de las cosas por ser el representante de Dios en la tierra, como lo fue David.

La representación de la Justicia en las Biblias boloñesas, además de figurar la virtud simboliza el ejercicio del derecho, disciplina que en esos momentos se imparte en las Universidades; especialmente en la de Bolonia cuando se están ilustrando los manuscritos bíblicos al mismo tiempo que otros de carácter jurídico. ${ }^{51}$

Representacion de la Justicia en la Biblia boloñesa del Palacio Real de MADRID (MS. II-330) (Figuras 1 y 2)

La Justicia se representa a través de las siguientes imágenes:

1.-Figura de rey que ciñe una corona sobre su cabeza, empuña una espada levantada a través de su mano derecha mientras que con la izquierda sostiene una balanza (Figura 1). La represtación tiene lugar en la inicial «0» del folio 273 del Libro de la Sabiduría.

La imagen hace alusión a los versículos $(1,1-9)$ del Libro, en el que se contiene la idea de que la Justicia correctiva ha de ser un atributo del rey:

«Amad la justicia los que gobernáis la tierra; pensad rectamente del Señor y buscadle con sencillez de corazón. Porque se deja hallar de los que no la tientan, se manifiesta a los que no desconfían de El (...) Por esto nadie que hable impiedades quedará oculto, ni pasará de largo ante él la Justicia vengadora. Porque los pensamientos del impío serán examinados; y hasta al Señor llegará el sonido de sus palabras, para el castigo de sus iniquidades» (Sab 1, 1-9).

El origen divino del poder está presente en este Libro y de la misma manera, que Dios pedirá cuentas de ese poder a quienes lo ostentan:

\footnotetext{
12.

${ }^{50}$ Cavero Domínguez, Gregorio; Fernández González, Etelvina y Galván Freile, Fernando, Ibídem:

${ }^{51}$ El Derecho, según Jacques Verger, se impartía como disciplina en el studium de las Universidades creadas a partir de escuelas que ya existía como organismos autónomos de naturaleza corporativa. La autonomía de estas escuelas posibilitaban la libertad de contratación de maestros, la dotación de un estatuto, y la implantación de una observancia o una determinada disciplina colectiva a sus miembros. La Universidad, en cierto modo, especie de federación de escuelas, en determinados casos enseñaban una sola disciplina: en Bolonia el Derecho y en Montpellier la Medicina. Es a mediados del siglo XIII cuando el Papa unifica esas nuevas corporaciones educativas bajo el concepto de Studium generale. A partir de esos momentos las disciplinas que predominaban en esas Universidades eran el Derecho civil y el Derecho canónico» (Verger, Jacques. 1999. Gentes del saber en la Europa de finales de la Edad Media en: La mirada de la Historia: 62-64. Madrid. Edit. Complutense.)
} 


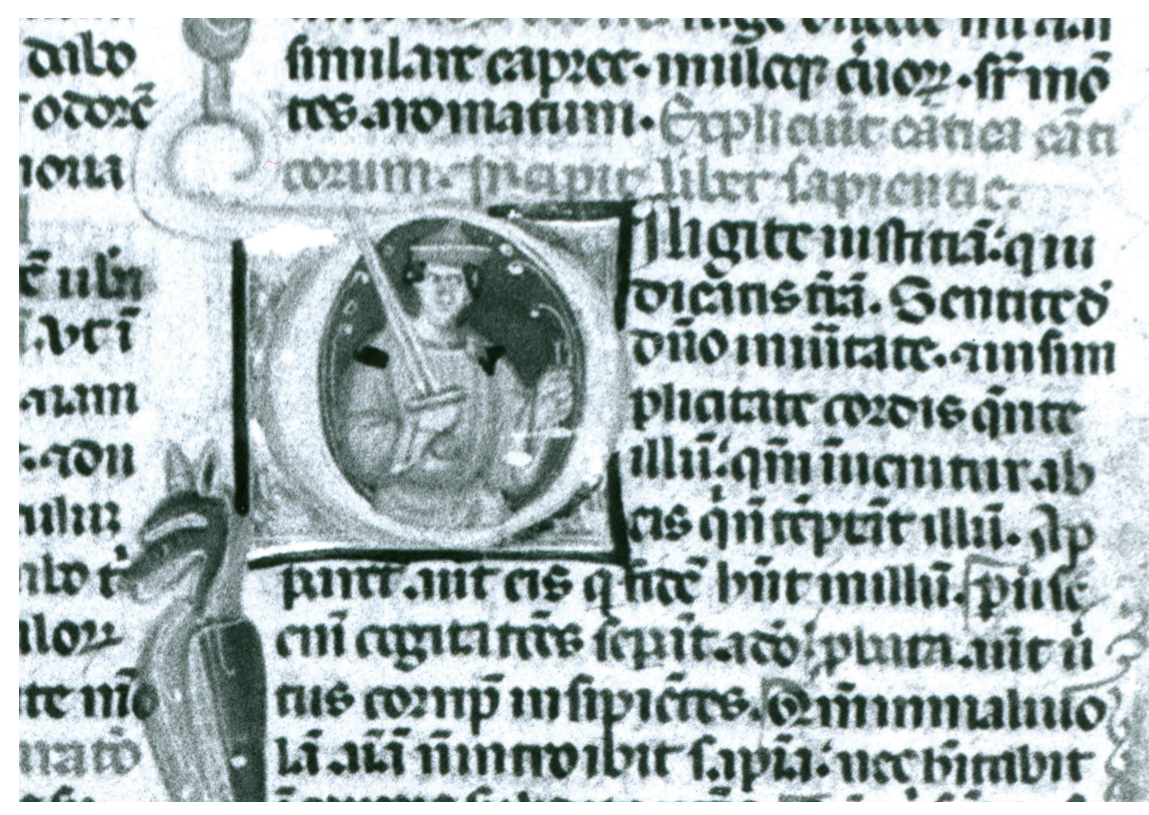

Figura 1.

Biblia del Palacio Real de Madrid (ms. II-330), Sabiduría, fol. 273 (detalle de la Inicial O). Alegoría de la Justicia: rey coronado con espada y balanza.

Fotografía de la colección personal de la autora.

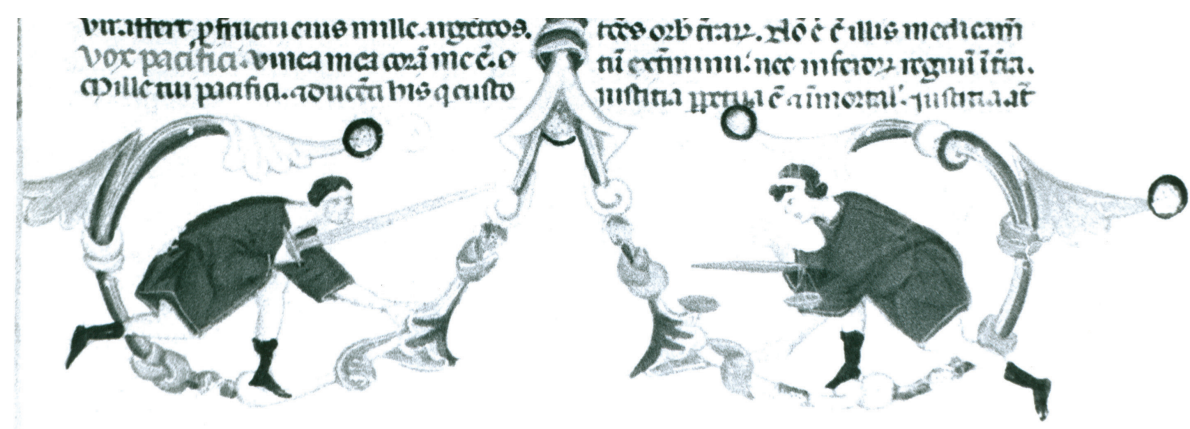

Figura 2.

Biblia del Palacio Real de Madrid (ms. II-330), Sabiduría, fol. 273 (margen inferior). Alegoría de la Justicia: emisarios de la justicia, delegados del poder.

Fotografía de la colección personal de la autora. 
«Oíd, pues, reyes, y entended. Aprended los que domináis los confines de la tierra (...) los que imperáis sobre las muchedumbres (...) Porque el poder os fue dado por el Señor, y la Soberanía por el Altísimo, que examinará vuestras obras y escudriñará vuestros pensamientos. Porque siendo ministros de su reino no juzgasteis rectamente y no guardasteis la Ley, ni según la voluntad de Dios caminasteis (...) de los que mandan se ha de hacer severo juicio (...)» (Sab 6, 1-5).

El personaje representado es un rey que ciñe corona y lleva los símbolos de la Justicia en sus manos: la espada y la balanza. La espada ejecutora de la Justicia, la balanza regula con el fiel las buenas y malas acciones según se inclinen sus platillos hacia un lado u otro.

La corona y la espada son dos de los elementos que forman parte de los «ritos de coronación» en el uso de las insignias en la Edad Media. Son los símbolos del poder y autoridad real del monarca medieval. ${ }^{52}$ La espada, es el símbolo del poder del monarca como ministro de Dios para ejercer la justicia. Representa el poder del rey que deberá restablecer la paz en el orbe cristiano. Como símbolo del poder político del rey es el símbolo de la defensa del reino y de la Iglesia. Con la espada, expulsará y sancionará a los enemigos, internos y externos, a los herejes y cismáticos [a los necios e incrédulos, al impío], para hacer vigente la paz, la equidad, la justicia. Todos los testimonios medievales están de acuerdo en que el «poder político» se justifica por el cumplimiento de dos misiones: defensa de la Iglesia y restablecimiento de la paz y Justicia para asegurar en la tierra el «orden social» imagen del «orden sobrenatural».

El análisis iconográfico nos lleva a interpretar a un rey que ejerce y ama la Justicia, por ello lleva los símbolos de la espada y la balanza. La espada de doble filo arma más eficaz y tajante (Heb 4, 12-13) y la balanza en perfecto equilibrio símbolo de la equidad en la medida justa. En este sentido la representación se ajusta de un modo directo al versículo primero: «Amad la Justicia los que gobernáis la tierra $(\ldots) »($ Sab 1,1$)$.

Como norma general, en la Edad Media, la Justicia es el símbolo del poder real ${ }^{53}$ El gobernante ejercerá su «poder político» en defensa de la cristiandad de enemigos internos y externos entre ellos los herejes e infieles dentro y fuera de sus fronteras. El hereje es considerado como disidente religioso a la vez que era

\footnotetext{
${ }^{52}$ Mateu y Llopis, Felipe. 1962-1963 «Sacra Regia Aragonum Maiestas. Notas sobre la diplomática y simbología real» en: Homenaje a Johannes Vincke 11 de mayo de 1962. Vol. I: 201. Madrid: Consejo Superior de Investigaciones Científicas (en adelante CSIC). Entre otras insignias cita: manto, túnica, collar, cetro, escudo y otras según los casos y situaciones. Por estas insignias se reconoce su posesión y el comienzo de su ejercicio.

${ }^{53}$ Cavero Domínguez, Gregorio; Fernández González, Etelvina y Galván Freile, Fernando, Ibídem: 3: «En el Liber Iudicum se manifiesta el carácter sagrado del Derecho, y la Justicia es un atributo real que debía ser vigilada y protegida por los reyes, a los que se consideraba guardianes de ella».
} 
delincuente político por dos razones: porque delinquía contra el verdadero rey, por alta traición, y alteraba la unidad del reino al quebrantar el orden social. ${ }^{54}$

2.-Representación de dos emisarios de la Justicia, el de la derecha sostiene una balanza y el de la izquierda empuña la espada. (Figura 2). La representación tiene lugar en el margen inferior del folio.

Los personajes son simétricos y adoptan idénticas posturas al situarse sobre el tallo del orlado sobre el que se sujetan, al mismo tiempo que portan objetos iconográficos alusivos a la Justicia. Los dos personajes representan a los emisarios de Dios y del rey, en su misión de ejercer la Justicia a lo largo del camino que recorren.

De modo accesorio, los dos personajes completan la escena principal que se contiene en la inicial, ajustándose al versículo ocho:

«Por eso nadie que hable impiedades quedará oculto, ni pasará de largo ante él la justicia vengadora» $(\mathrm{Sab} 1,8)$.

Los delegados del poder, personajes situados sobre la orla en situación de marcha, buscan en su camino al que se oculta, a pesar de las dificultades que ofrece el tallo sobre el que hacen verdaderos equilibrios para evitar su caída.

En la Edad Media, el poder temporal del rey -en materia religiosa- puede delegarse a sus vasallos (fideles); porque al igual que Dios ejerce su gobierno en la tierra mediante sus vicarios para establecer el orden jurídico mediante el derecho natural y el derecho divino; de la misma manera el rey en la tierra es ayudado por la curia regia. ${ }^{55}$

La acción de los emisarios en la búsqueda y seguimiento de la justicia se puede interpretar como persecución de herejes e infieles que obran en contra la Iglesia y quebrantan el orden social. A partir de 1220 en la declaración de herejía sería formulada por las autoridades eclesiásticas y los castigos temporales, responsabilidad de los poderes laicos. ${ }^{56}$

${ }^{54}$ García Pelayo, Manuel. 1959. El reino de Dios arquetipo político. Estudio sobre las formas políticas en la Alta Edad Media: 143-147. Madrid: Revista de Occidente.

${ }^{55}$ A medida que se desarrolla la escolástica, se va imponiendo de forma muy clara la distinción entre el derecho natural y el derecho divino. El ejemplo lo tenemos en Guillermo d' Auxerre hacia 1230: García Pelayo, Manuel, ibídem: 88.

${ }^{56}$ Los delitos de herejía se consideran «delitos de lesa majestad» en los Concilios de Verona de 1181 y Letrán de 1215. La regulación de la persecución de la herejía, por parte del poder real, termina con las leyes de Federico II en 1220 con el inmediato establecimiento de la Inquisición: García Pelayo, Manuel, Ibídem: 87, 147. 
Representación de la Justicia en Biblia de la Catedral del Burgo de Osma (ms/3).

La representación de la Justicia se manifiesta a través de las siguientes imágenes:

3.-Figura de rey que ciñe corona, empuña y sostiene una espada, y se comunica con dos personajes que a juzgar por sus vestimentas son «cortesanos». (Figura 3). La represtación tiene lugar en la inicial «0» del folio 231 del Libro de la Sabiduría, espacio en el que se representa a un rey, coronado, vestido con túnica rosa y manto azul cobalto ultramar sentado en un trono con escabel a sus pies. El trono parece representar un edificio civil, posiblemente el palacio. La actitud de éste rey es la de sostener una espada desnuda de doble filo en posición vertical con su mano izquierda, mientras que con el dedo índice de la derecha parece estar dando órdenes o instrucciones a los dos hombres que se encuentran próximos a él en disposición de escucha y atención. El primer personaje, que a la vez se disponen a escuchar, mantiene el brazo derecho velado por el manto. ${ }^{57}$ La imagen hace alusión a Sabiduría $(1,1)$ : «Amad la justicia los que gobernáis la tierra».

$\mathrm{Al}$ parecer, el rey se encuentra vinculado con el personaje (cortesano) situado en primer término por el color rosa de la indumentaria; de tal manera que la túnica rosa del monarca se corresponde con el manto igualmente rosa de este personaje. De la misma manera se establece otra correspondencia entre ambos por el color azul cobalto del manto del monarca con la túnica del mismo color que viste el personaje. Otro personaje situado en segundo término, aparece en este escenario ataviado con una túnica y manto del estilo del anterior. ${ }^{58}$

\footnotetext{
${ }^{57}$ Los gestos, actitudes y movimientos son signos del lenguaje usados en liturgia. El signo de las manos veladas cubiertas con el extremo del palio, un velo o paño, para transportar objetos sagrados aparece desde muy antiguo en representaciones del arte paleocristiano de las catacumbas romanas. El gesto de indicar señalando es un gesto de actitud. Un análisis de estos gestos en el primitivo arte cristiano véase en: Kirschbaum, Engelberto; Junyet, Eduardo y Vives, José. 1954. La tumba de San Pedro y las catacumbas romanas. Los monumentos y las inscripciones: 376-377. Madrid: Editorial BAC.

${ }^{58}$ El color rosa de la túnica del rey le vincula con los reyes israelitas David y Salomón a lo largo de las representaciones iconográficas del Antiguo Testamento en este manuscrito. La tradición judeocristiana consideraba autor de éste libro a Salomón, por lo que es posible que el artista, a través del color rosa, quiera evocar al rey sabio, posible autor de este Libro. Véase el análisis del color de esta Biblia en: Martínez Murillo, $M^{\mathrm{a}}$. Concepción. 1991. Estudio Iconográfico y Estilístico de las «Biblias Boloñesas» en España (Reino de Castilla). Madrid: Editorial Complutense. Tomo II: 1266-1306. Es posible relacionar el color rosa -utilizado en liturgia a partir del siglo xIII, durante la «Tercera Domínica de Adviento» (Gaudete) - con la idea de justicia que se contiene en la tercera venida de Cristo, como «juez», sin descartar la evocación a la «Cuarta de Cuaresma» (Laetare) tiempo en el que la Iglesia ora constantemente y en el que también se usa ese color; aunque me inclino por la primera hipótesis. Ver Martínez Murillo, Ma . Concepción. 2006. «Simbolismo del color en la iconografía de la Biblia boloñesa del Palacio Real de Madrid, ms. II-330». Goya. Revista de Arte. nº.313-314: 196-210.
} 


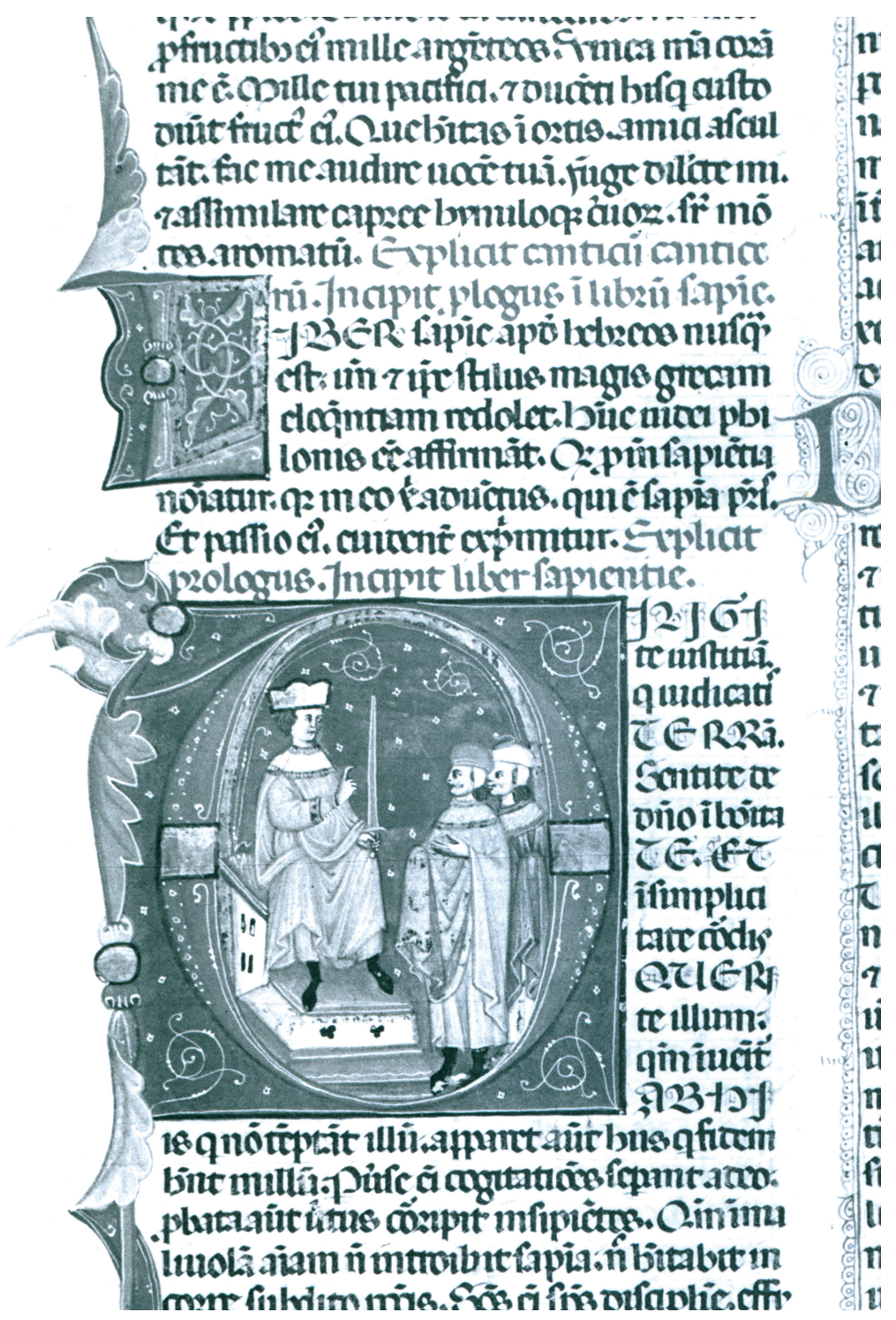

Figura 3.

Biblia de la Catedral del Burgo de Osma (Ms/3), Sabiduría, fol. 231 (detalle de la Inicial O). Alegoría de la Justicia: rey coronado con espada dando instrucciones a los delegados del poder.

Fotografía de la colección personal de la autora. 
Las vestiduras de los personajes son típicamente medievales y se corresponden con el tiempo cronológico en el que se ilustra el manuscrito.$^{59}$ Es lo que cabe esperar, en líneas generales, en las Biblias de Bolonia, para representar a personajes atemporales acordes con la impersonalidad del texto. Así pues, los personajes de este Libro se desligan del tiempo cronológico bíblico.

La actitud por la que un personaje situado en primer término cubre su brazo y mano hacia otro de mayor honor o condición social, es señal de respeto y veneración; tal es la relación que existe entre el monarca y el primer cortesano. La mayor dignidad corresponde al rey, que ejerce la Justicia (ostenta los atributos simbólicos de la Justicia: corona y espada) ante los dos cortesanos, y es por lo que se le representa, además, sentado en un trono y con un escabel a sus pies. El rey tenía la obligación de velar para que se ejerciera un derecho justo y se mantuviera la Justicia». ${ }^{60}$

La Justicia, como en el antiguo oriente, es el símbolo de la monarquía, de la virtud del rey; se asocia a su figura, como se observa a través del Liber Iudiciorum o Lex Visigothorum, ${ }^{61}$ obra traducida en el siglo XIII del latín (Libro de los Juicios / Liber Iudicum, etc., conocido y usado en la Edad Media en la redacción del «Decreto Graciano».

El mensaje de la representación del conjunto de la escena que se ilustra en el Libro de la Sabiduría del manuscrito Ms/3, es la siguiente: el artista traduce un suceso o acto, que tiene lugar entre un rey (vicario de Dios) y unos cortesanos (pueden ser jueces o emisarios de la justicia), para interpretar el concepto de «justicia medieval». A través de dicho concepto entendemos que el rey, que es rey por la gracia de Dios, representa a los gobernantes de la tierra y los cortesanos son la imagen de los delegados del poder. La escena es alegórica por la

${ }^{59}$ A través de la iconografía del traje podemos observar que se trata de un tipo de vestimenta medieval de los siglos XIII y XIV, específicamente la que corresponde a la baja Edad Media. En la figura del rey y en la de los personajes que le escuchan, la prenda de vestir, «manto» es semejante a la de los trajes cortesanos de la época de los «minnesänger» alemanes de los siglos XII y XIII que aparecen en el «Cancionero de Manesse» (Manesse Liederhandssiften), conservado en la Biblioteca de la Universidad de Heidelberg. El tipo de prenda consiste en un largo manto sobre el que se coloca una especie de piel blanca de «armiño» que cae desde el cuello hasta los hombros. Este tipo de manto es semejante al «casacón de paño» que, también se adornaba con una pequeña franja blanca en el cuello, era utilizado por los burgueses del siglo XV en Italia. Respecto al tocado de la cabeza masculina que lucen los dos personajes, esta prenda es semejante al «sombrero de paño» superpuesto al «bonete blanco con barbera»de 1350 utilizado en Italia y que solían llevar las personas de elevada condición social: (Véase Brun-Tilke. 1962. Historia del Traje en Imágenes: 28, 32, 37, 53. Barcelona: Gustavo Gili)

${ }^{60}$ Según se observa en el Libro Juzgo. Véase Cavero Domínguez, Gregorio; Fernández González, Etelvina y Galván Freile, Fernando, Ibídem: 8.

${ }^{61}$ Cuyo antecedente es el Breviario de Alarico en Italia y el Código de Leovigildo para los visigodos. 
impersonalidad del relato en relación al libro de (Sab 1, 1): «Amad la justicia los que gobernáis la tierra» y en consecuencia se representa a través de personajes atemporales ajenos al tiempo bíblico.

La representación es similar a la escenificada en la Biblia anterior. El artista interpreta la virtud de la Justicia en la figura de un rey teocrático y, simboliza, el poder puesto a prueba que emana de esa Justicia, a través de los cortesanos (burgueses de la época), posiblemente representantes de los jueces en quienes delega la Justicia el rey, como se contiene en el Libro Juzgo. ${ }^{62}$

Representación de la Justicia en la Biblia boloñesa del Real Monasterio de El EsCORIAL (ms. a. I. 5).

Las representaciones son las siguientes:

4.-Representación de la «sabiduría coronada» en la figura de un personaje coronado y entronizado, que empuña una espada ligeramente inclinada a través de su mano derecha, mientras que a través de la izquierda sostiene un libro abierto. (Figura 4). Posiblemente se represente a Salomón, rey sabio que ejerció la Justicia. La escena, una vez más, vuelve a estar representada en la inicial «0» del folio 259 del Libro de la Sabiduría.

Es común ver representaciones conjuntas del libro y la espada en ceremonias de investidura solemnes de «jueces de Estado» en el arte bizantino del siglo XIV para prestar juramento de sus cargos. ${ }^{63}$ La representación del libro, como objeto sagrado, forma parte de los ritos de coronación, como he descrito anteriormente. También se asocia a la representación de la Justicia como símbolo de la Ley contenida en las Sagradas Escrituras. La imagen del rey hace alusión a la defensa de la Ley. La asociación conjunta del Libro y la espada, en la figura del rey (cargo supremo que representa la justicia del Estado) quiere, además, representar el compromiso del ejercicio del derecho.

Los ritos de consagración real para la ascensión al trono se verificaban con arreglo a los ordines o ritos de coronación. Los ritos tenían lugar en el oficio de la misa, en el que era imprescindible la presencia de los «libros litúrgicos» y los «actos políticos» que describe García Pelayo. La coronación real era sanción y garantía litúrgica por la que el rey, desde el momento de ser coronado, era

${ }^{62}$ Liber Iudiciorum. Libro 2, «Sobre la jurisdicción de los nombramientos»: por esta jurisdicción se delega la Justicia en los jueces existentes y, mediante esa jurisdicción, los jueces podían atender tantos casos civiles como criminales. El nombramiento de juez correspondía al rey y la vigilancia de quien ejerciera esa Justicia recaería en el cargo de juez que fuera nombrado por el dux.

${ }^{63}$ Caballo, Guglielmo. 2008. «El libro en Bizancio» en: Lecturas de Bizancio. El legado escrito de Grecia en España: 16. Madrid: Biblioteca Nacional de España.

Hispania Sacra, LXVII

135, enero-junio 2015, 7-47, ISSN: 0018-215X, doi: 10.3989/hs.2015.001 


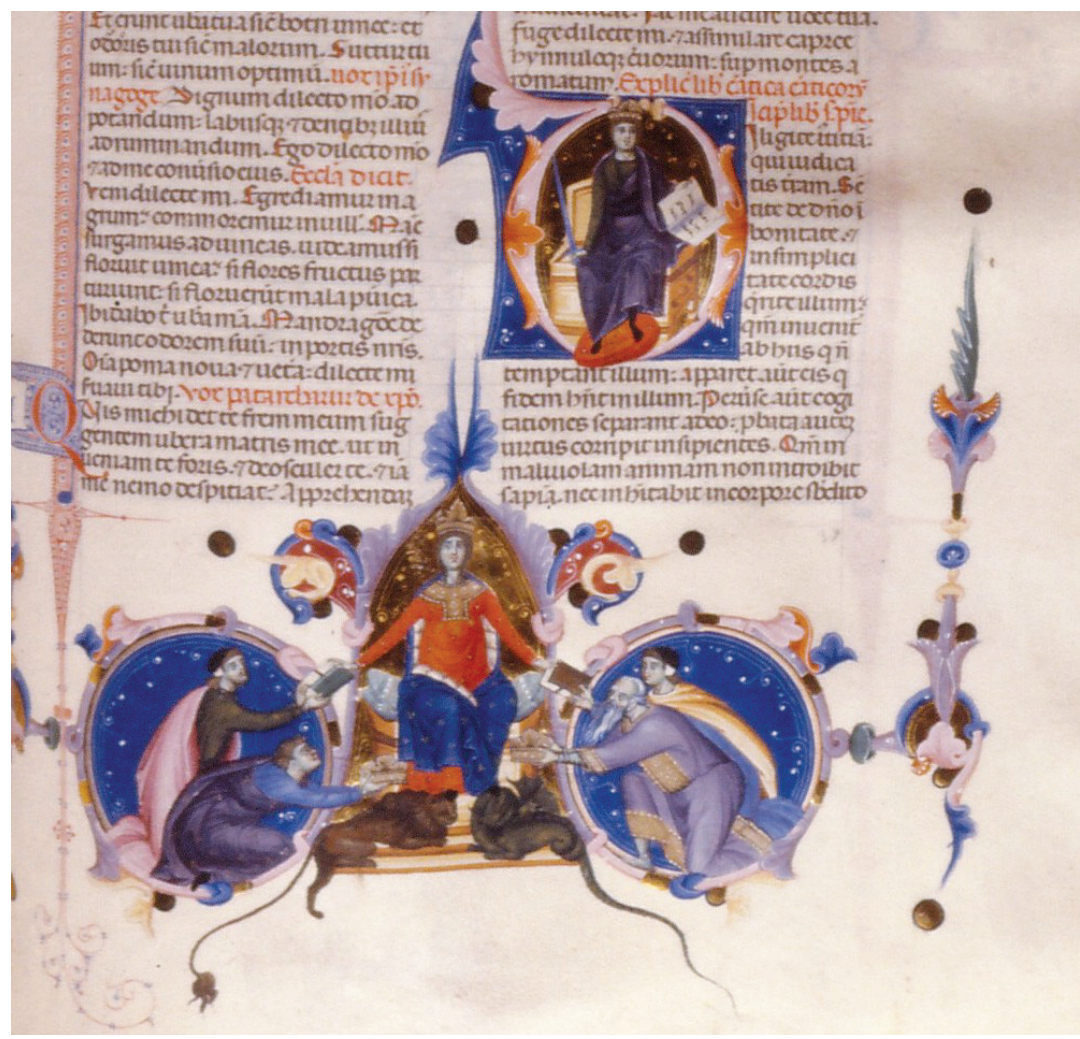

Figura 4.

Biblia del Real Monasterio de El Escorial (ms. a. I. 5), Sabiduría, fol. 259 (detalle de la Inicial O). Alegoría de la sabiduría: rey entronizado, coronado con espada y libro. Margen Inferior del folio: apoteosis de la Sabiduría.

Fotografía de la colección personal de la autora.

concebido como vicario de Dios. En el rito formaban parte las insignias reales: corona, espada, anillo, cetro, globos (en algunos casos vestiduras sacerdotales, etc.) y la recepción de las insignias y las aclamaciones o laudes. De todas las insignias la más importante era la corona y su entrega constituía la traditio regni destinada por Dios al monarca que le convertía en rey «por la gracia de Dios» y en cuyo nombre le era impuesta por los sacerdotes. El rey, una vez efectuado el rito de la coronación, se convertía en Deo coronato. ${ }^{64}$

\footnotetext{
${ }^{64}$ García Pelayo, Manuel, Ibídem: 111.
} 
La iconografía de este pasaje es clara: en la letra capital se representa al rey sabio Salomón, entronizado, coronado, sosteniendo la espada de la Justicia ligeramente inclinada a través de su mano derecha al mismo tiempo que por la izquierda muestra y sujeta un libro abierto, probablemente la Sabiduría anhelada y cantada tantas veces por él: «Dios de los padres y Señor de la misericordia (...) $\mathrm{Y}$ en tu sabiduría formaste al hombre (...) Dame la sabiduría asistente de tu trono y no me excluyas del número de tus siervos (...) Tu me elegiste para rey de tu pueblo y juez de tus hijos y de tus hijas (...) Contigo está la sabiduría, conocedora de tus obras (...) Mándala (...) que me asista en mis trabajos» (Sab $9,1-11)$. Es la visión de un rey coronado dispuesto a dictar y ejercer la Justicia conforme a las normas o la Ley.

Otra representación -en el mismo folio, y en la margen inferior-alusiva a la mencionada virtud es la de la Sabiduría sentada en un trono y a sus lados, figuras de reyes y jueces en actitud de ofrecer coronas y libros.

En el margen inferior del folio se representa la alegoría de la apoteosis de la sabiduría a través de una imagen que ostenta los atributos reales: entronizado, coronado, vestido con vestiduras sacerdotales reales (palio bizantino) y manto estrellado símbolo del elegido, a lo que se añade los caracteres propios de la sabiduría: el acto de recibir y entregar libros. A este rey le rinden pleitesía altos dignatarios (probablemente sacerdotes, ministros) que le ofrecen coronas y libros. Este rey tiene como escabel a sus pies, un león y un dragón. El león simboliza al pueblo judío y el dragón al enemigo, según versículos (Sab 10, 11) en los que se narra el castigo sufrido por los egipcios por no atender a la sabiduría. La sabiduría, en esta representación, somete a las fieras. Queda además representada en esta imagen de forma indirecta, el ministerio sacerdotal del rey en la Edad Media como rex sacerdos, por recibir la corona de manos de dignatarios eclesiásticos, haciéndole partícipe del ministerio sacerdotal, todavía presente en el siglo siglo XII en el ordo ecclesiasticus del officium ecclesiasticum de emperadores y reyes. ${ }^{65}$

Los atributos iconográficos de este manuscrito, en general, son los mismos que los que aparecen representados en las biblias anteriores: la espada, elemento iconográfico símbolo de la Justicia y, por consiguiente, de la virtud de la sabiduría. La Sabiduría contiene todas las demás virtudes: «Y si amas la justicia, los frutos de la sabiduría son las virtudes, porque ella enseña la templanza y la prudencia, la justicia, y la fortaleza, las virtudes más provechosas para el hombre en la vida» Sabiduría $(8,7)$.

El conocimiento de la Sabiduría a través de la palabra, de la instrucción y la observación en las Leyes, viene referida en (Sab 6, 9-18):

${ }^{65}$ García Pelayo, Manuel, Ibídem: 114.

Hispania Sacra, LXVII

135, enero-junio 2015, 7-47, ISSN: 0018-215X, doi: 10.3989/hs.2015.001 
«A vosotros pues reyes, se dirigen mis palabras, para que aprendáis la sabiduría y no pequéis (...) y quienes hubieran aprendido sabrán como responder. Ansiad, pues, mis palabras deseadlas e instruios (...); la observancia de las leyes asegura la incorrupción».

De la misma manera la representación de rey con el Libro, simboliza la Sabiduría contenida en las Escrituras. El mensaje determinante de la escena representada es hacer ver al lector/ espectador, que la virtud de la Justicia contiene a todas las virtudes.

La representación del rey en la inicial evoca la figura de un rey teocrático con carácter sagrado que representa la Sabiduría, como correspondería a Salomón, vestido con túnica y manto pisando una especie de escabel (cojín de color bermellón) símbolo de su dignidad real. Las ofrendas hechas al rey, representadas a través de las coronas y libros, son similares a las que encontraremos en el Libro Eclesiastés de la Biblia del Burgo de Osma (Ms/3). En este manuscrito los obsequios de los súbditos reviven la idea de la presentaliter y el principio teocrático de la realeza. La ofrenda del libro es el símbolo del Libro Eclesiástico que representa las leyes reales capitularia legibus addenda o novas leges. Nos encontramos ante un tipo de figuración semejante en la que el rey, Salomón, símbolo de la Sabiduría, se figura como a un rey teocrático con carácter sagrado Imperatur Dei Gratia recibiendo las novas leges y la corona como la presentaliter símbolo de su poder y de su dominio sobre sus súbditos.

Nos volvemos a encontrar ante una alegoría en la que los personajes son imprecisos en cuanto al tiempo en el que tiene lugar el relato representado. Por ello, las imágenes se relacionan indirectamente con el texto. Los personajes (dignatarios) se descontextualizan en el tiempo del relato, según podemos advertir a través de las prendas de vestir típicamente medievales: el tocado de la cabeza es una especie de barbera y el palio bizantino.

Concluyo con las palabras de San Isidoro de Sevilla acerca de la Sabiduría, uno de los nombres que recibe Cristo en las Escrituras: «Sabiduría porque revela los misterios de la ciencia y los arcanos de la sabiduría». ${ }^{66}$

Representación de la Justicia en las Biblia boloñesa de la Biblioteca Nacional (VIT. 21-4)

Representación de la sabiduría [y de la ley] en la figura de un rey con espada y balanza. (Figura 5). En la inicial «O» en el Libro de la Sabiduría, fol. 240v

\footnotetext{
${ }^{66}$ San Isidoro de Sevilla. 1951. Etimologías. Libro 7/ Cap. II: 164. Madrid: BAC.
} 


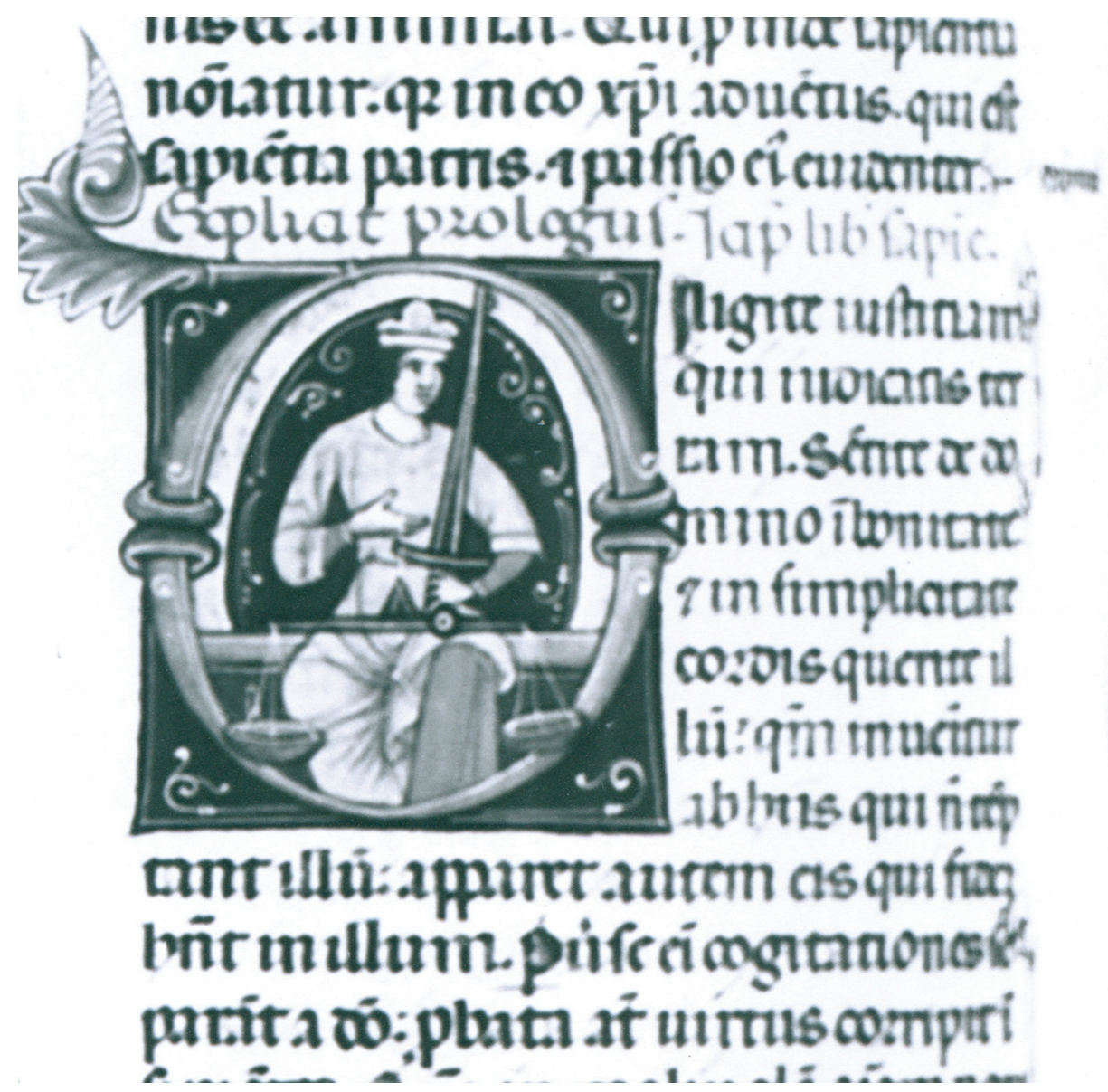

Figura 5.

Biblia de la Biblioteca Nacional (Vit. 21-4), Sabiduría, fol. 240v. (detalle de la Inicial O). Alegoría de la Justicia: rey coronado empuña la espada y equilibra el fiel de la balanza.

Fotografía de la colección personal de la autora.

Hispania Sacra, LXVII

135, enero-junio 2015, 7-47, ISSN: 0018-215X, doi: 10.3989/hs.2015.001 
La imagen guarda una gran semejanza con la representada en la Biblia del Palacio Real de Madrid II-330.

Se representa a un rey coronado, sentado en una especie de travesaño que cruza la inicial. Su actitud es la de sostener, a través de su mano y brazo izquierdo, la espada muy destacada de doble hoja al mismo tiempo que la muestra mediante el gesto de su mano derecha. De su pierna izquierda flexionada pende una balanza de dos platillos. La balanza no está equilibrada, a juzgar por el fiel y uno de sus platillos, que están inclinados hacia su derecha, pero que a través del gesto de su mano diestra parece intentar equilibrar el fiel.

Se representa la virtud de la Justicia en ejercicio, a través de un rey coronado que muestra su poder a través de la espada con el que ha de restaurar un orden desequilibrado.

Representación de la Sabiduría en la figura de un rey (Cohelet) en la Biblia del Burgo de Osma (ms/3, fol. 229 v). Eclesiatés. (Figura 6).

El Libro se relaciona indirectamente con la Justicia, como caso excepcional en estas Biblias. La representación de la Sabiduría se representa a través de un rey entronizado, Cohelet. Este tipo de representación es similar a la escena figurada en el margen inferior del $m s$ a. I. 5 descrita anteriormente.

El Eclesiastés es un libro en cierto modo impersonal cuya figura principal es Cohelet, que puede o no identificarse con Salomón. Según una tradición transmitida por San Jerónimo el Libro se atribuye a Salomón. La tradición se apoya en la sentencia que parece confirmarse a través de los siguientes versículos: «Yo Cohelet, he sido rey de Israel en Jerusalen» $(\mathrm{Ecl} 1,12)$.

Nos encontramos ante un Libro en el que el artista, como en otras ocasiones, transmite la idea a través de una imagen indirecta ${ }^{67}$ En este caso escoge la figura de un rey, símbolo de poder. Se le representa rey teocrático (imperatur Dei gratia) en sus dos facetas. Primero, como rey de Israel por el ejercicio de su función civil, a través de la cual legisla; aspecto éste que se representa a través de las insignias reales: cetro, la corona, el trono y el globus sostenido en su

\footnotetext{
${ }^{67}$ Una ilustración igualmente indirecta aparece en el libro Eclesiastés del ms. II-330. Allí se representa la transmisión de la Sabiduría a través de una gran «bola de oro» (Sol) que un monje entrega a un joven que, a su vez, la recibe en actitud reverente. La representación se ajusta a los versículos del Eclesiastés $(1,1-4)$ sobre la entrega de la Sabiduría de la antigua generación (monje) a otra generación más joven. La representación de la «gran bola dorada» simboliza la luz de la Sabiduría: «(...) Me volví a mirar la sabiduría (...) Y ví que la sabiduría sobrepuja a la ignorancia cuanto la luz a las tinieblas (...) Por eso aborrecí la vida, al ver que cuanto debajo del sol se hace, todo es vanidad (...) y aborrecí todo cuanto se había hecho bajo el sol» (Ecl 2, 12-20)
} 


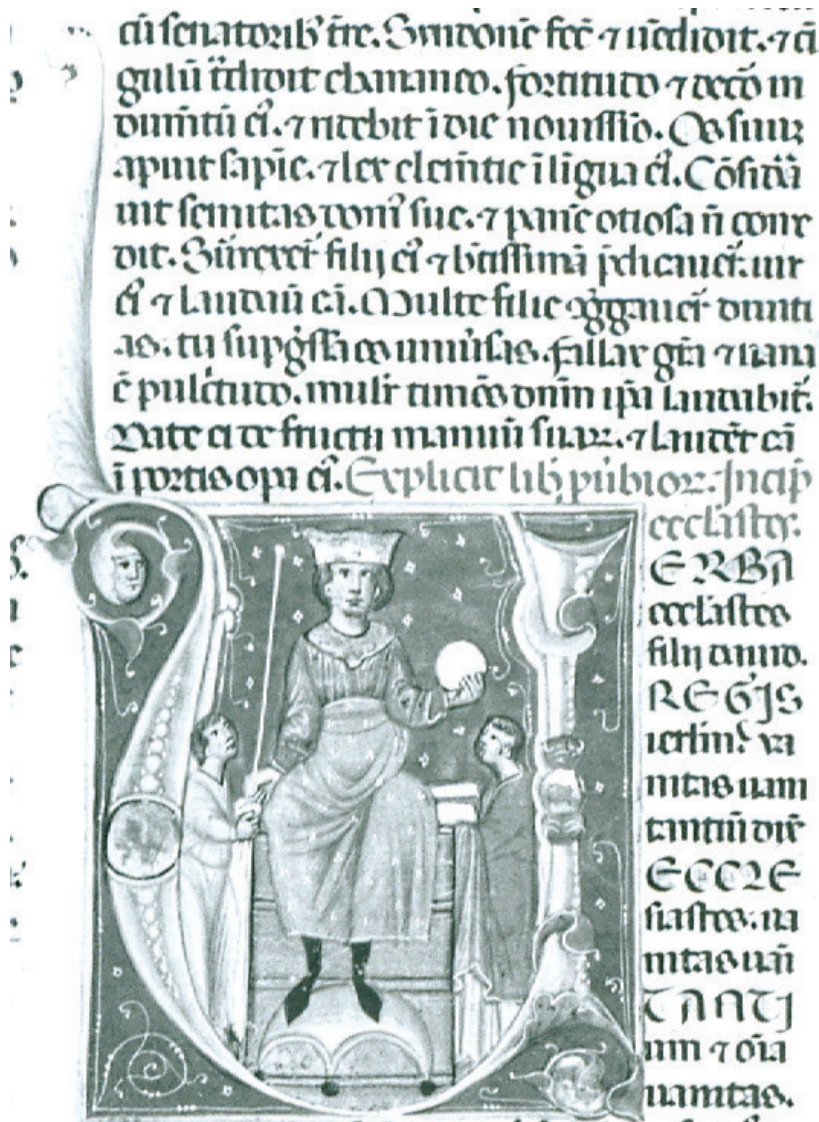

Quobtamplỉ

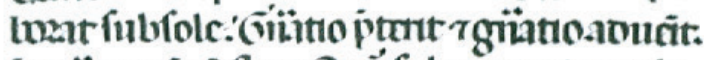

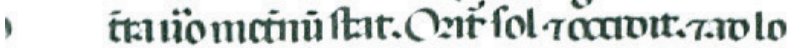

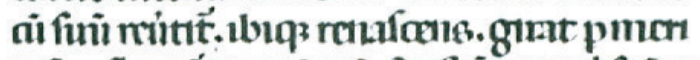

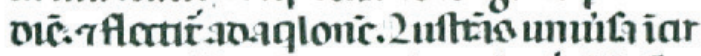

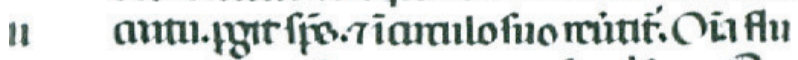

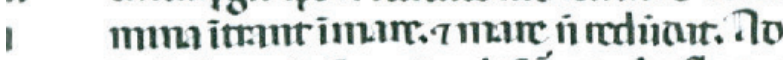

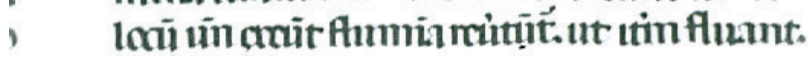

Figura 6.

Biblia del Burgo de Osma (Ms/3), Eclesiastés, fol.229v. (detalle de la Inicial U). Alegoría de la Sabiduría en la figura de un rey teocrático (imperatur Dei gratia) recibiendo las novas leges o capitularia legibus addenda. Presentaliter.

Fotografía de la colección personal de la autora. 
mano derecha, símbolo de la sabiduría. ${ }^{68}$ Segundo, como supremo sacerdote por su función eclesiástica a través de viejos símbolos que se vienen arrastrando. Tiene a sus pies la bóveda del templo como escabel y su manto está sembrado de estrellas designándolo como al elegido. En este rey se representa a Salomón, supuesto Cohelet, rey pacífico y amado del Señor, el que corrige las costumbres, enseña ciencia natural y marida a Cristo con la Iglesia. ${ }^{69}$

La escena se representa sobre un fondo bermellón oscuro estrellado y sobre éste, la imagen de un rey coronado, sentado en su trono, vestido con túnica verde esmeralda y manto verde azulado sembrado de estrellas, en actitud de agarrar con su mano derecha el cetro o vara símbolo de la Justicia y equidad. Con la izquierda sostiene una pequeña bola blanca (globus), símbolo de autoridad y poder. Por su expresión podemos observar que su mirada está perdida y parece ausentarse de la atenta mirada de dos personajes que le llevan ofrendas y están situados a su diestra y a su siniestra. Este rey apoya sus pies sobre un escabel con forma de bóveda semiesférica, posiblemente la bóveda de un templo, sobre la que asienta su potestad. Se evoca aquí el concepto medieval de presentaliter por la que Dios está presente en el mundo a través de su vicario. Se representa el principio teocrático de la realeza por el que la ofrenda del Libro simboliza la ley (capitularia legibus addenda o novae leges) y la soberanía o potestad del rey sobre la iglesia. La presencia de Dios se evidencia a través de la cara lunar, símbolo de la presencia divina, encerrada en el roleo izquierdo del tallo que forma en el ángulo izquierdo la inicial «U» en la que se contiene la escena. El simbolismo de esta imagen es constante a través de las Biblias boloñesas.

La escena ofrece en su composición un gran paralelo con la Biblia de Viviano (Bibl. Nat. De París) de la primera mitad del siglo Ix, en la que se representa a Carlos el Calvo sentado en un trono y ante él unos frailes, uno de ellos con las manos veladas, que le ofrecen un libro (presentación de la Biblia).

Finalmente, es interesante observar que este modo de representar la Justicia es perdurable, a grandes rasgos, a lo largo del tiempo. Encontramos exactamente los mismos esquemas en el siglo xv, por ejemplo, en la Biblia de la catedral de Plasencia (Figura 7).

${ }^{68}$ Considero la «bola» (globus) en estas Biblias como símbolo de la Sabiduría por el paralelismo con la «bola dorada» que se representa en el mismo libro en el $m s$. II-330. La «bola» es el símbolo imperial, símbolo del globo terrestre, atributo del poder temporal. En el arte bizantino es frecuente ver este símbolo que proviene de los emperadores romanos. Ver Brun-Tilke. 1962: 25 del texto y 27 de imágenes. En los iconos bizantinos la «bola» sencilla aparece sostenida en ocasiones por ángeles (ejemplo: Arcángel Gabriel ataviado con ropa imperial sostiene la bola con la mano izquierda mientras que con la mano derecha agarra una lanza en: El arte en la Servia medieval de los siglos XII al XVII. 1981. Catálogo del Ministerio de Cultura: 26 y 54. Madrid: Museo del Prado.

${ }^{69}$ San Jerónimo, Ibídem. Vol. I: 445. 


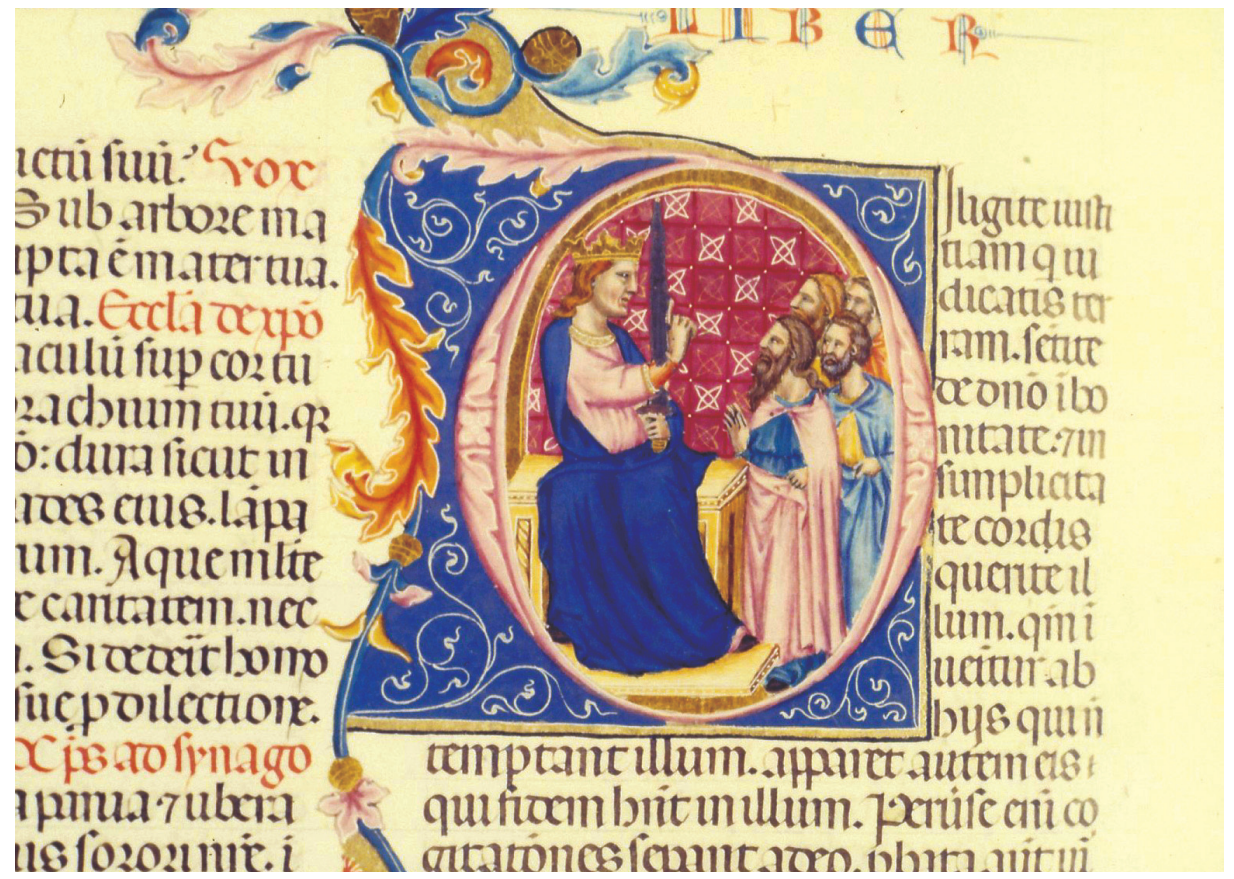

Figura 7.

Biblia de la Catedral de Plasencia. Sabiduría. Detalle de la inicial «O». Alegoría de la Justicia: rey coronado con espada dando instrucciones a los delegados del poder.

Fotografía de la colección personal de la autora. 


\section{ConClusiones}

En general, las imágenes alusivas a la Justicia testimonian la importancia del Derecho en Europa, especialmente en Bolonia en los siglos XIII y XIV, y particularmente en relación con las Sagradas Escrituras.

Esas imágenes se concentran en el Libro de la Sabiduría y ocasionalmente, en el Eclesiastés.

La imagen de la Justicia es siempre una representación de tipo masculino. La Justicia se representa en la figura de un rey con espada, libro y en ocasiones, con balanza.

Ejercer con acierto la Justicia se manifiesta como una de las virtudes de la sabiduría y por consiguiente, del poder real. El rey es el delegado de Dios que con sabiduría ejerce la Justicia en la tierra.

La representación del rey justo, en las Biblias medievales procedentes de Bolonia recae en Salomón, prototipo de rey sabio, espejo de reyes, en el que se representa el concepto medieval de rey teocrático con carácter sagrado (imperatur dei gratia) en actitud de recibir las leyes nuevas (novas leges) y la corona como símbolo de su poder (presentaliter). Este tipo de representaciones alegorizan el contenido de las Escrituras.

La representación de la Justicia en las Biblias boloñesas trasmite el concepto aristotélico tomista del ejercicio de las virtudes morales, políticas y sociales ejercidas a través de los gobernantes de le tierra representados en la figura de Salomón.

Otro tipo de representación relacionada con la Justicia, en las Biblias boloñesas, es la Apoteosis de la Sabiduría o Justicia bien ejercida por los gobernantes de toda la tierra, reconocida por reyes y sabios. La Sabiduría contiene todas las virtudes y entre ellas la Justicia.

La iconografía representada en el Libro de la Sabiduría de las Biblias boloñesas tiene similitud con las imágenes de la Justicia que ilustran el Decretum Gratiani y el Infortiatum boloñés. 


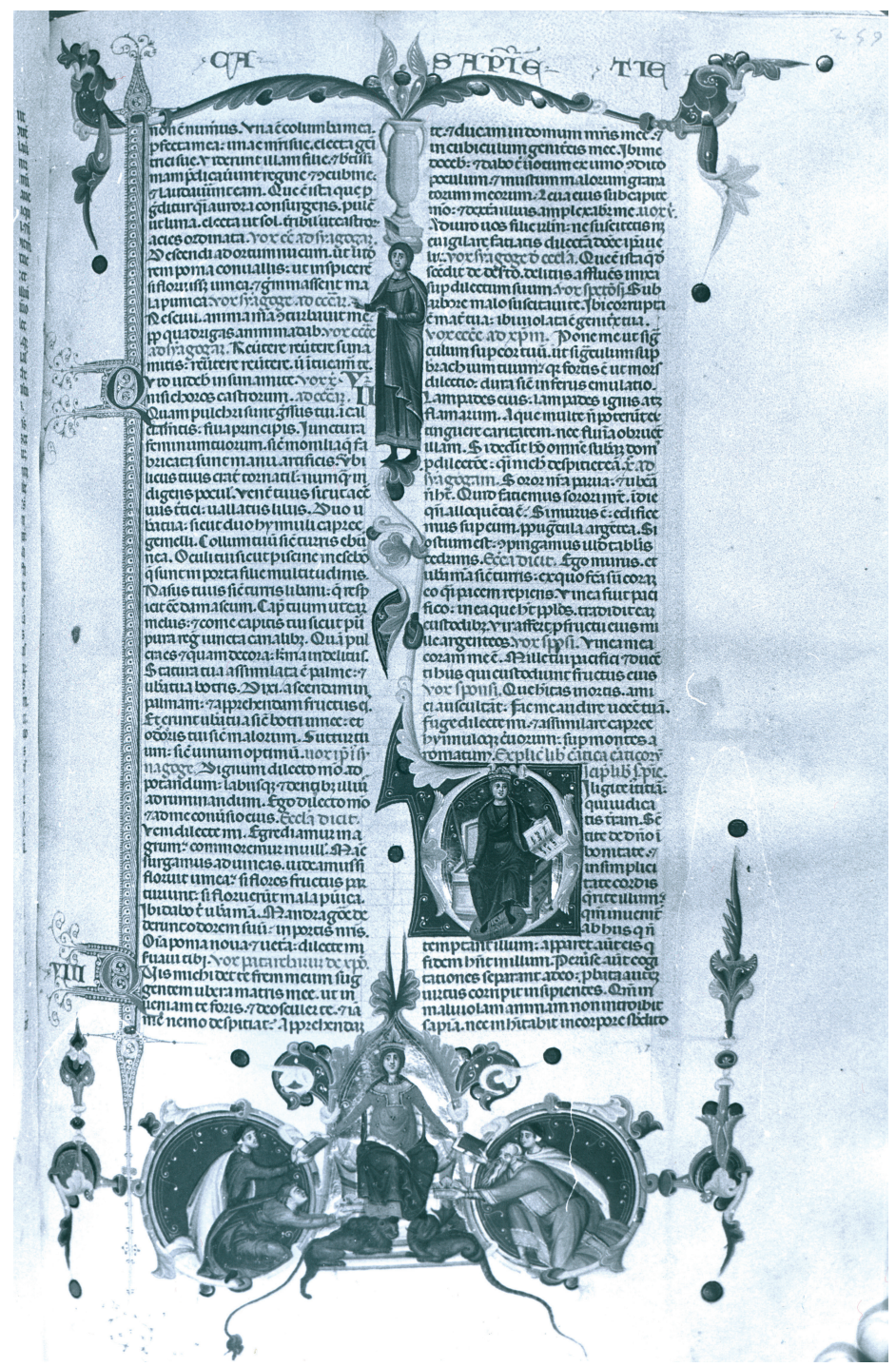

Figura 1.

General.- Biblia del Real Monasterio de El Escorial (ms. a. I. 5), Sabiduría, fol. 259 (detalle de la Inicial O). Alegoría de la sabiduría: rey entronizado, coronado con espada y libro. Margen Inferior del folio: apoteosis de la sabiduría. Personaje indicativo (orlado central).

Fotografía de la colección personal de la autora.

Hispania Sacra, LXVII

135, enero-junio 2015, 7-47, ISSN: 0018-215X, doi: 10.3989/hs.2015.001 


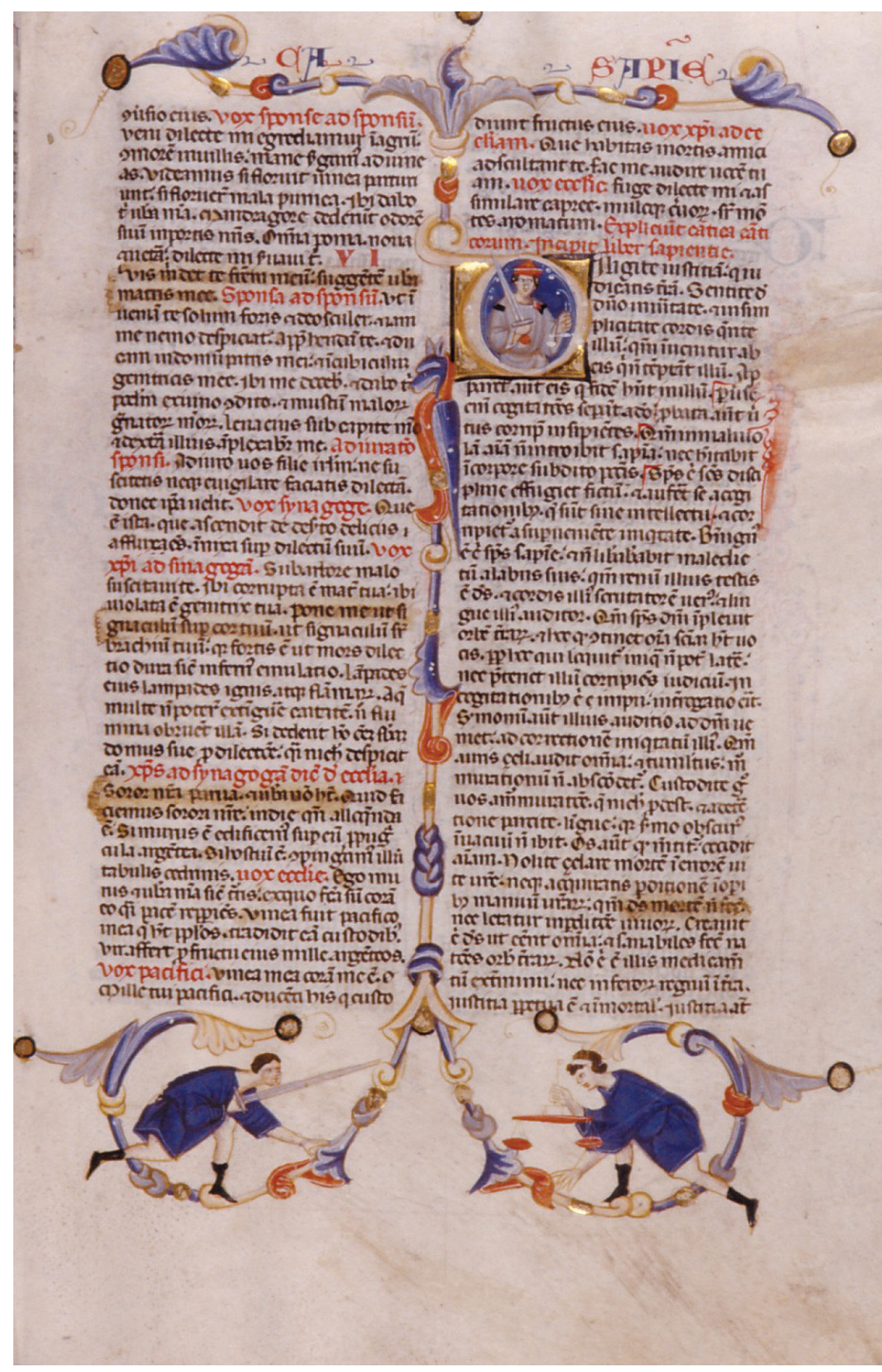

Figura 2.

General.- Biblia del Palacio Real de Madrid (ms. II-330), Sabiduría, fol. 273. (detalle de la Inicial O). Alegoría de la Justicia: rey coronado con espada y balanza (Inicial O) y representación de los delegados del poder (margen inferior).

Fotografía de la colección personal de la autora. 
BIBLIOGRAFÍA

Antolín, Guillermo. 1916. Catálogo de los Códices Latinos de la Real Biblioteca de El Escorial. Vol. IV: 332. Madrid: Imprenta Helénica.

Ayuso Marazuela, Teófilo. 1953. La Vetus Latina Hispana. Tomo I: 379. Madrid.

Bohigas, Pere. 1980. «En qué medida el estudio histórico de las Bibliotecas contribuye al conocimiento de los contactos culturales en la Edad Media». Boletín de la Anabad. XXX: 209-224.

Braudrillard, Alfred. 1937. Dictionnaire d'Histoire et de Geographie Eclesiastiques. Tom. IX: 648-659. París.

Brun-Tilke. 1962. Historia del traje en imágenes. Barcelona: Gustavo Gili.

Burke, Peter. 2001. Visto y no visto. El uso de la imagen como documento histórico. Barcelona: Crítica.

Caballo, Guglielmo. 2008. «El libro en Bizancio» en: Lecturas de Bizancio. El legado escrito de Grecia en España. Madrid: Biblioteca Nacional de España.

Catálogo Real Biblioteca del Monasterio de El Escorial. Búsqueda en catálogo: http://rbme.patrimonionacional.es/Busqueda-en-Catalogo. aspx?id=4

Castiñeiras González, Manuel Antonio.1998. Introducción al método iconográfico. $1^{\mathrm{a}}$ edición. Barcelona: Editorial Ariel, S. A.

Cavero Domínguez, Gregorio; Fernández González, Etelvina y Galván Freile, Fernando. 2007. «Imágenes reales, imágenes de justicia en la Catedral de León» en: e-Spania [puesto en línea el 26 de junio de 2007, 25 noviembre 2009] en: <http://espania.revues.org/document204.> DOI del artículo: 10.4000/e-spania.204 (Consulta 5/6/2013) y en http://e-spania.revues.org/204 (8/ 9/ 2014).

Congar, Y. M. J. 1981. La fe y la teología. $3^{a}$ versión castellana de Enrique Molina. Colección: El Misterio Cristiano. Teología Dogmática nº.10. Barcelona: Herder.

Contreras, Sebastián. 2012. «La justicia en Aristóteles. Una revisión a las ideas fundamentales de Ethicae Nicomachea». Ágora. Estudios Clásicos en Debate. 14: 63-80.

De Silva y Verástegui, Soledad. 1991. «Contribución al estado de la cuestión de los estudios iconográficos en los manuscritos jurídicos ilustrados de la Edad Media». Cuadernos de Arte e Iconografía. Tom. IV, no 7, en: <http://www.fuesp.com/revistas/ pag/cai0715.html> (Consulta 26/7/2013).

De Frachet, Gerardo. 1966. «San Pedro de Verona, su martirio»: Vida de los frailes predicadores»: Santo Domingo de Guzmán. Su vida. Su obra. Madrid: Biblioteca de Autores Cristianos.

De la Torre, Martín y Longás, Pedro. 1935. Catálogo de Códices Latinos. Tom. I . Madrid: Patronato de la Biblioteca Nacional. Ver en: <http://rbme.patrimonionacional. es/Busqueda-en-Catalogo.axp?id=4 > (Consulta 24.09.2013). 
Dictionnaire de Spiritualité (Ascétique et Mystique, Doctrine et Histoire). 19321988. Marcel Viller S. J. (Director). F. Cavallera y J. De Guibert, S.J. (colaboradores): 12 vols., Beauchesnes-París.

Dolcini, Carlo. 2007. «Lo Studium fino al XIII sécolo» en: Storia di Bologna . Tom. 2: Bologna nel Medioevo. Direttore Renato Zangheri a cura di Ovidio Capitani. Bononia: University Press; Fundazione Cassa di Risparmio in Bologna, Instituto per la Storia di Bologna.

Domínguez Bordona, Jesús. 1925. «Miniaturas Boloñesas del siglo XIV». Archivo Español de Arte y Arqueología 4: 177-188.

Domínguez Bordona, Jesús. 1933. Manuscritos con pinturas. Notas para un inventario de los conservados en colecciones públicas y privadas. 2 Tomos: Tom. I (ÁvilaMadrid), Tom. II (El Escorial-Zaragoza). Centro de Estudios Históricos. Fichero de Arte Antiguo Madrid: Imprenta Blass. S. A.

Dominique, Pierre. 1969. L'Inquisition. París.

Fernández Conde, J. 1982. «Aplicación de las reformas del Lateranense IV» en: Historia de la Iglesia en España, Vol. II-2 ${ }^{\circ}$. Madrid: Biblioteca de Autores Cristianos.

Formentín, Justo y Martínez Murillo, Ma . Concepción. 1994. «Influencia de la Leyenda Dorada en la literatura y en el arte medieval, a través de dos Biblias Boloñesas localizadas en España»: Hispania Sacra, vol. XLVI, nº. 93: 65-139.

Franco Mata, Ángela. 1998. Escultura gótica en León y provincia 1230-1530. León: Instituto Leonés de Cultura y Diputación de León.

García Pelayo, Manuel. 1959. El reino de Dios arquetipo político. Estudio sobre las formas políticas en la Alta Edad Media. Revista de Occidente, S. A., Madrid.

Gebhart, Emilio. 1943. La Italia mística. Historia del Renacimiento religioso en la Edad Media. Buenos Aires.

Grabar, André. 1985. Las vías de la creación en la iconografía cristiana. Versión española de Francisco Díez del Corral. Barcelona: Editorial Alianza Universidad. Colección Alianza Forma.

Hernández, Gabriel. 2009. «Origen de las Universidades en Italia». Revista Educación y Desarrollo Social, Bogotá, DC. Colombia, vol. 3, n¹: 182-190.

IBIS. Base de datos del patrimonio bibliográfico de Patrimonio Nacional <http:// realbiblioteca.patrimonionacional.es/cgi-bin/koha/opac-detail.pl?biblionumber=387> (Consulta 06/9/2014).

Kirschbaum, Engelberto; Junyet, Eduardo y Vives, José. 1954. La tumba de San Pedro y las catacumbas romanas. Los monumentos y las inscripciones: 376-377. Madrid: Biblioteca de Autores Cristianos.

Koudelka, Vladimir J. 1968. Bibliotheca Sanctorum. Tom. X: 748. Instituto Giovanni XXIII della Pontificia Universitá Lateranense. Roma. 
Ladero Quesada, Miguel Ángel. 1987. Historia Universal. Edad Media. Vol. II: 542. Barcelona: Vicens-Vives.

Mateu y Llopis, Felipe.1962-1963 «Sacra Regia Aragonum Maiestas. Notas sobre la diplomática y simbología real» en: Homenaje a Johannes Vincke 11 de mayo de 1962. Vol. I: 201. Madrid: CSIC.

Martínez Millán, José. 1980. «En torno al nacimiento de la Inquisición medieval a través de la censura de libros en los reinos de Castilla y Aragón 1232-1480». Hispania, $\mathrm{n}^{\circ} 144:$ 5-35.

Martínez Murillo, Mª . Concepción. 1991. Estudio Iconográfico y Estilístico de las «Biblias Boloñesas» en España (Reino de Castilla). 3 Vols. Tesis doctoral. Madrid: Editorial Complutense.

Martínez Murillo, Ma de la Concepción y Formentín Ibáñez, Justo. 1995.«Iconografía relacionada con la vida de los santos en algunas miniaturas de la «Biblia boloñesa del Real Monasterio de El Escorial» (a. I. 5). Influencia de la Leyenda Dorada». Hispania Sacra XLVII, nº 96: 695-745.

Martínez Murillo, Ma de la Concepción. 1999. «Las Biblias boloñesas medievales y la defensa de la ortodoxia a través de sus imágenes», en: V Simposio Bíblico Español. La Biblia en el Arte y en la Literatura. II Arte: 321-338. Universidad de Navarra. Valencia-Pamplona.

Martínez Murillo, Ma de la Concepción. 2006. «Simbolismo del color en la iconografía de la Biblia boloñesa del Palacio Real de Madrid, ms. II-330». Goya. Revista de Arte, $\mathrm{n}^{\circ} .313-314: 196-210$.

Millares Carlo, A. 1929. Paleografía Española, Vol. I. Barcelona-Buenos Aires 1929.

Millares Carlo, A. 1933. Introducción a la historia del libro y de las bibliotecas. Madrid.

Muratori, L. A. 1912-1932. Storici Italiani. T. XVIII-Part. I/L. Vol. II. Corpus Chronicorum Bononiensium. Cittá di Castello.

Llorca, B; García Villoslada, R.; De Leturia, P.; Montalban, F. J. 1953. Historia de la Iglesia Católica. Tom. II: 594-595. Madrid: Biblioteca de Autores Cristianos.

Llorente, Juan Antonio. 1822. Historia crítica de la Inquisición en España. Cap. XLVII: 22-23. Madrid.

Panofsky, Erwin. 1976. Estudios sobre iconología. Prólogo de Enrique Lafuente Ferrari. Versión española de Bernardo Fernández, $2^{\text {a }}$ edición. Madrid: Editorial Alianza Universidad.

Pavón Ramírez, Marta. 2007. Manuscritos de derecho canónico iluminados: los Decretales de Gregorio IX de la Biblioteca Apostólica Vaticana. Tesis Doctoral. Barcelona.

Pons Gurí, Joseph Ma . 1974. «Constituciones conciliares tarraconenses 1229-1330». Analecta Sacra Tarraconensia. Vol. XLVII: 65-129. 
San Isidoro de Sevilla, Etimologías. 1951: primera versión, traducción y notas de Luís Cortés y Góngora. Introducción general e Índices de Santiago Montero Díaz. Madrid: Biblioteca de Autores Cristianos.

San Jerónimo. 1962. Cartas de San Jerónimo. 2 Vols. Edición bilingüe latín-castellano. Introducción, versión y notas de Daniel Ruiz Bueno. Madrid: Biblioteca de Autores Cristianos.

Sánchez Mariana, Manuel. 1996. El Libro en la Baja Edad Media. Reino de Castilla, en: Historia ilustrada del Libro Español. Cap. 9: «Los manuscritos». $2^{\circ}$ edición. Madrid: Fundación Germán Sánchez Ruipérez y Ediciones Pirámide.

Sosa, G. 1966. El arte del libro en la Edad Media, Buenos Aires.

Rodríguez López, Blanca. 2013. «Por qué ser justos ¿son las normas de justicia sociales o morales?». Revista Internacional de Sociología, vol 72, n 2: 261-280 y en <http:// revintsociologia.revistas.csic.es/index.php/revintsociologia/article/view/511/533> (Consulta 24/5/2013).

Rodríguez López, María Isabel. 2003. «La imagen de la Justicia en las artes plásticas. Desde la antigüiedad hasta las postrimerías del medioevo»: Saberes. Revista de estudios jurídicos, económicos y sociales. Vol. I: 1-26 y en: <http://www.uax.es/publicaciones/archivos/SABSOC03_006.pdf> (Consulta 24/5/2013).

Rodríguez López, María Isabel. 2006. «La imagen de la Justicia en la Edad Moderna: génesis y análisis iconográfico». Anales de Historia del Arte 16: 112.

Sagrada Biblia. 1958. Versión directa de lenguas originales por: Nácar Fuster, Eloíno; Colunga, Alberto; Cigognani, Gaetano, 8 a edición. Madrid: Biblioteca de Autores Cristianos.

Salmi, Mario. 1962. La miniatura Italiana. Obra traducida por Juan G. Basté. Barcelona: Labor, S. A.

Sebastián López, Santiago. 1996. Mensaje simbólico del arte medieval.Arquitectura, liturgia e iconografía. $1^{\mathrm{a}}$ edición. Madrid: Ediciones Encuentro.

Smith, Damián. 2013. «Cruzada, herejía e inquisición en tierras de la Corona de Aragón SS. XII-XIII». Hispania Sacra. Vol. LXV (Extra I): 29-48.

Verger, Jacques. 1999. Gentes del saber en la Europa de finales de la Edad Media. Colección: La mirada de la Historia». Madrid: Edit. Complutense.

Villaseñor Sebastián, Fernando. 2013. «La corte literaria de Juan de Zúñiga y Pimentel (Plasencia, 1459-Guadalupe, 1504) en: Anales de Historia del Arte 23: $\left(\mathrm{n}^{\mathrm{o}}\right.$ especial II) 581-594.

Yarza, Joaquín. 2006. «Manuscritos iluminados boloñeses en España. Siglos XIIIXIV»: España y Bolonia. Siete siglos de relaciones artísticas y culturales. Obra dirigida por Joaquín Colomer y Amadeo Serra Desfilis. Madrid: Fundación Carolina y Centro de Estudios de Europa Hispánica. 